\title{
Preliminary analysis of the Late Natufian ground stone from Shubayqa 1, Jordan
}

\author{
Patrick Nørskov Pedersen, Tobias Richter, Amaia Arranz-Otaegui \\ Department of Cross-Cultural and Regional Studies, University of Copenhagen, Building 10, Karen Blixens Vej \\ 4, 2300 Copenhagen-S, Denmark. \\ Email: Nørskov Pedersen: patrick-n-p@hotmail.com; Richter: richter@hum.ku.dk; \\ Arranz-Otaegui: kch860@hum.ku.dk
}

\begin{abstract}
:
Shubayqa 1 is a newly identified early and late Natufian site in the harra desert of northeastern Jordan. In addition to buildings, and rich chipped stone, faunal, and botanical assemblages, the site has produced a large collection of ground stone tools. This paper presents the result of a preliminary study of the ground stone artefacts associated with the late Natufian phase. Results indicate that while the assemblage is overall very similar to other Natufian sites in the Mediterranean zone, there are also some notable differences. Although grinding rather than pounding tools appear to be more important at the site, many tools were seemingly involved in both grinding and pounding activities. We hypothesize that this dual function could be explained by the processing of rhizome tubers, which were found in abundance at the site, and which may have represented an important food source for the inhabitants. In addition, we argue that the relationship between ground stone tools and cereal processing has been overemphasized and the processing of other plant food resources, in this case tubers could have been equally significant. While the processing of plant foods was one function, many tools are also associated with pigment stains, suggesting that they were involved in the processing of non-vegetal matter.
\end{abstract}

Keywords: ground stone tools; mortars; Late Natufian; Shubayqa 1; Jordan

\section{Introduction}

One of the key characteristics of the Late Epipalaeolithic in the Levant is the proliferation of ground stone tools, particularly at Natufian sites (Bar-Yosef 1998; BelferCohen 1991; Wright 1991; 1994; Belfer-Cohen \& Hovers 2005). Although they are by no means absent from pre-Natufian contexts (Wright 1991; 1994; Peterson 1999; Maher et al. 2012), it is during the Late Epipalaeolithic that they occur in large numbers with assemblages exhibiting a greater variety of tool types. The assemblages from this time period also sometimes include decorated or finely made ground stone artefacts (e.g., Perrot 1966; Valla \& Christensen 2012; Edwards 2013, fig. 8.9). Much previous research on Late Epipalaeolithic ground stone tool industries has focused on the southwestern part of the Levant, since this

Published by the School of History, Classics and Archaeology, University of Edinburgh ISSN: 2055-0472. URL: http://journals.ed.ac.uk/lithicstudies/

This work is licensed under a Creative Commons Attribution 2.5 UK: Scotland License. 
area has the longest history of research (Rosen 1991). In this paper we provide a preliminary overview of the ground stone tool assemblage from the late Natufian phase at Shubayqa 1, which is situated in the harra desert of northeast Jordan (Richter et al. 2012; 2014). This recently excavated settlement has produced an extraordinarily large assemblage of ground stone tools, which provides critical insights into the site's function, economy and activities of the site's inhabitants. Furthermore, the Shubayqa 1 assemblage can be readily contextualised against a rich dataset of chipped stone tools, fauna and botanical remains, the latter of which have rarely survived at other Natufian sites in the southern Levant. In this paper, we primarily focus on the late Natufian ground stone tools from Shubayqa 1.

\section{Background}

Research into the Late Epipalaeolithic in the eastern part of the Levant began in earnest only in the 1980s with the initiation of large-scale fieldwork projects by Andrew Garrard and his team in the Wadi el-Jilat and the Azraq Oasis (Garrard et al. 1977; Garrard et al. 1985; Garrard et al. 1988; Garrard 1991; Garrard \& Byrd 1992; Garrard et al. 1994; Garrard 1998; Garrard \& Byrd 2013: 178-298). Surveys in the harra and hamad by Betts (Betts 1991; 1998: 11-36; Betts \& Helms 1991: 183-190), also produced evidence for significant Late Epipalaeolithic occupations in this region. Until recently, only four Late Epipalaeolithic sites were excavated in eastern Jordan: Azraq 18 (Garrard 1991; Garrard \& Byrd 2013: 291-297), Wadi Jilat 22 (Garrard \& Byrd 1992, 2013: 224-235), Khallat Anaza (Betts 1991; 1998) and Bawab al-Ghazal (Rollefson et al. 1999).

All of these sites, apart from Wadi Jilat 22, can be readily recognised as Natufian occupations (see Richter \& Maher 2013 for a more detailed discussion).

While these sites clearly demonstrate the presence of Natufian groups, Late Epipalaeolithic settlement in the Azraq Basin and Black Desert has often been described as ephemeral and less intensive when compared to sites in the Mediterranean zone, since eastern Jordan was only settled by Natufian groups as part of a reversion to higher mobility related to the onset of the Younger Dryas (Betts 1991; 1998; Bar-Yosef 1996; 1998; 2002; Bar-Yosef \& Belfer-Cohen 2000; Henry 2013). However, most Natufian sites in eastern Jordan are known only on the basis of - often unsystematic - surface collections, while none of the previously excavated Late Epipalaeolithic sites produced suitable samples for 14C dating (Richter \& Maher 2013). Ground stone tools from these sites were largely limited to small assemblages, which provide only limited insights into production methods, site function and economy. Recent work in the Qa' Shubayqa area has demonstrated not only that substantial Natufian settlements also existed in this region but, moreover, that some of these date back to the Early Natufian and were continuously occupied (Richter et al. 2014).

Shubayqa 1 is situated in the harra desert of the northeastern badya of Jordan, c. $20 \mathrm{~km}$ north of the town Safawi and approximately $130 \mathrm{~km}$ north-east of the Jordanian capital Amman (Figure 1). Badya refers to the arid zone located to the east of Amman continuing to the Jordanian/Iraqi border (Allison et al. 2000). The eastern part of this area can be separated into two regions: the harra, in the west, and the hamad in the east. While the hamad consists of chert gravels covering Cretaceous bedrock, the harra is defined by extensive basalt lava fields, which are interspersed by playas and dissected by wadis (Betts 1998: 1). The region nowadays receives less than $200 \mathrm{~mm}$ of mean annual rainfall and, in the area around the Qa' Shubayqa, is characterised by Saharo-Arabian type steppe vegetation (Zohary 1973: 101). The Shubayqa 1 site lies to the immediate north of an extensive playa or $q a^{\prime}$ which is fed by a series of wadis draining from the Jebel Druze to the northwest. Faunal and botanical evidence from the excavations suggest that the qa' was probably a semi-permanent to permanent wetland during the late Pleistocene. Shubayqa 1 is a c. 0.2 hectare large mound that rises 2-3 
meters above the surrounding area. Chipped stone and ground stone artefacts extend across an area of c. 4,000 $-5,000 \mathrm{~m}^{2}$ covering the mound and the area surrounding it. Several single and double boulder mortars were also found. The mound itself appears to consist of natural sediment, basalt boulders and anthropogenic deposits.

Since 2012 excavations have focused on one area situated to the immediate west of the mound's highest point (which is occupied by a recent Islamic tomb and can therefore not be excavated). The excavation area was targeted above a previous test excavation opened by Betts in the mid to late 1990s (Richter et al. 2012). Since the start of excavations this area has been extended to cover a total of $91 \mathrm{~m}^{2}$ (Figure 2). Excavations revealed a series of superimposed hut structures and other installations, as well as dense concentrations of chipped and ground stone artefacts, fauna, shell and stone beads, worked bone and charred plant remains. Stratigraphic observation, studies of tool types, and a series of 14C dates indicate that Shubayqa 1 was occupied during both the early and the late Natufian.

\section{Methodology}

This analysis includes only ground stone from the late Natufian occupation at the site, specifically material from deposits overlying the floor of Structure 2. This includes material from a series of midden deposits, as well as artefacts found lying directly on the floor of Structure 2. Due to uncertainties over their provenience, we have excluded surface finds from the present analysis. Ground stone from the early Natufian phase at Shubayqa 1 (phases 4-7) are presently being examined and will not be discussed here.

The analysis focused on technological and typological aspects of the ground stone assemblage. The classification and definition of tools types, tool morphology and technological terms are based on Wright (1992) and partly Adams (2002: 73-159), with a few modifications. These modifications entail the introduction of a "loaf-shaped handstone with tapering ends" type (see below) and a vessel mortar type dubbed "goblet", a type based on classification by Eitam (2009). A category of Unidentified Ground stone (UGS) was also introduced (see Section 4.7. below).

\section{The Late Natufian Ground Stone Assemblage}

\subsection{Raw material}

Given Shubayqa 1's location in the harra, a basalt dessert (Betts 1998; Richter et al. 2012), it is not surprising that the vast majority of the assemblage was made from locally available basalt. Only nine implements or fragments were of non-basaltic rock types (including flint, limestone, sandstone and pumice).

Basalt is a mafic rock type identified on the basis of its total alkali-silica content (Edwards 2013: 205 and references therein) with a hardness of six on the Mohs scale (Wright 1992). The basalt of the harra desert comprises four different lava flows starting in the Miocene and continuing into the Quaternary period from 8.9 to 0.1 mya (Allison et al. 2000). For the purpose of the present study we relied on macroscopic observations to determine different basalt raw material types. These were done without any visual aids and we used the number of vesicles, stone density and colour as means for sub-division (Table 1). Future geochemical or XRF analysis of the ground stone implements may aid in determining which types of basalts were preferred as raw material.

First, the basalt was divided into vesicular (I) and non-vesicular basalt (II). The vesicular category was further sub-divided into two more categories (III) and (IV) [Undetermined in the chart refers to where it was not possible to distinguish between three vesicular categories (I, III, IV), however these fall within the general vesicular category]. 


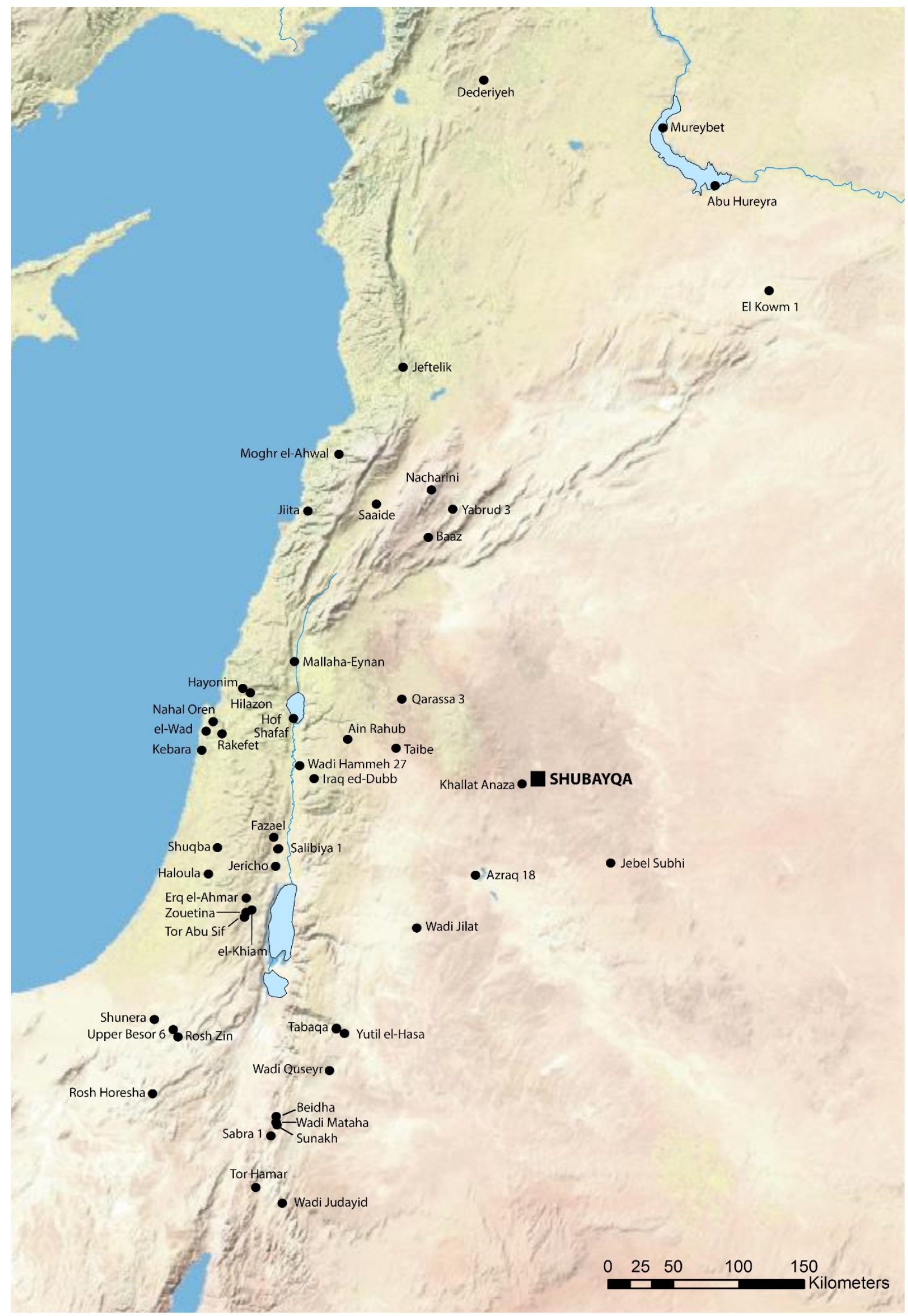

Figure 1: Location of Shubayqa 1 in relation to other Natufian sites. 

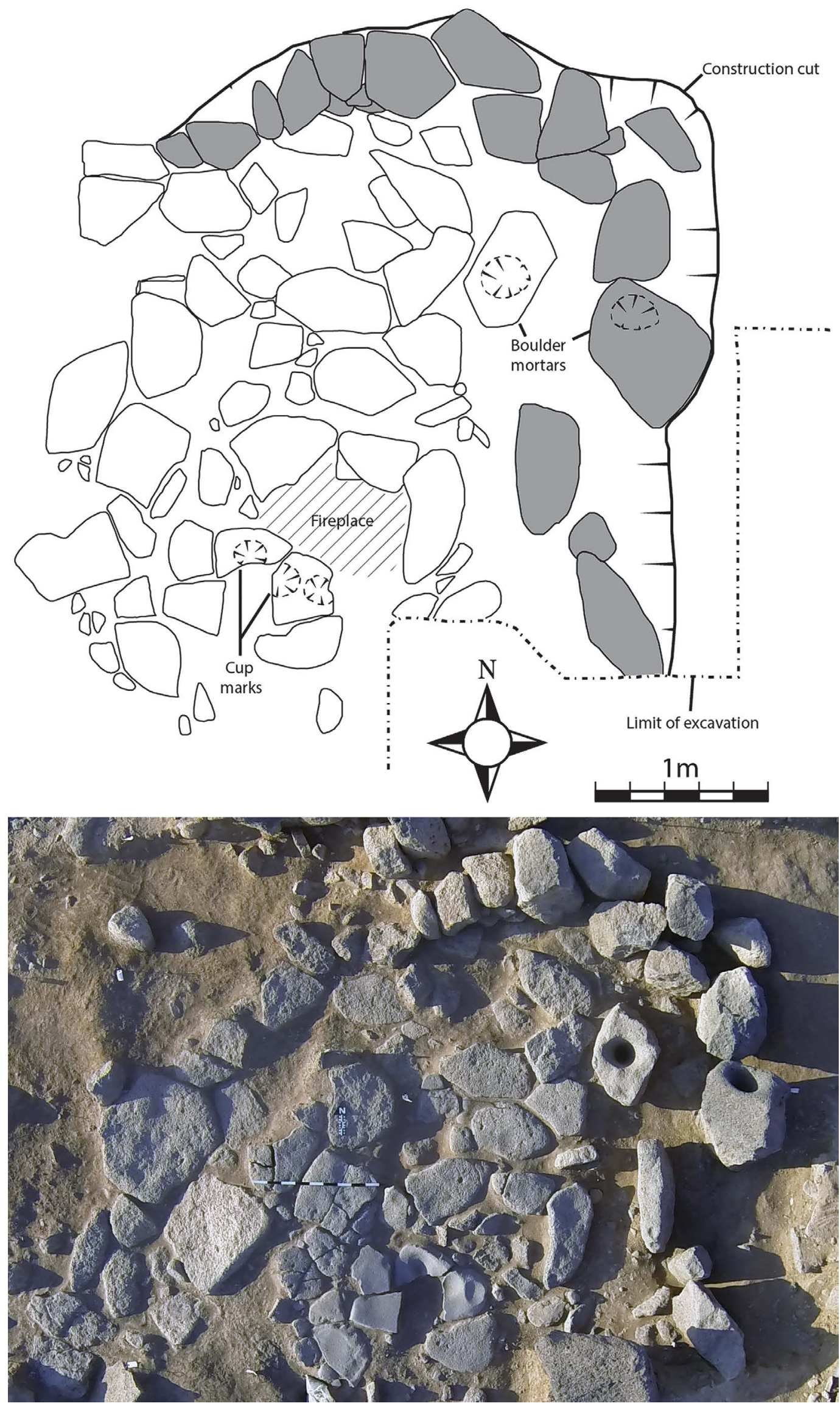

Figure 2: Overhead shot of Structure 2. Note the complete boulder mortar situated in the floor of the structure (see also Figure 9) 
Table 1. Basalts

\begin{tabular}{|c|c|c|}
\hline Basalt & Type & Description \\
\hline 1 & Vesicular Basalt & $\begin{array}{l}\text { Grey to dark grey, dense, very small (less than } 1 \mathrm{~mm} \text { ) and very } \\
\text { few vesicles ( } 3 \text { or less per } 5 \times 5 \mathrm{~mm} \text { area) }\end{array}$ \\
\hline II & $\begin{array}{l}\text { Non-vesicular } \\
\text { basalt }\end{array}$ & Blackish grey, extremely dense with no visible vesicles \\
\hline III & Vesicular Basalt & $\begin{array}{l}\text { Grey to dark grey, dense, small (1-2 } \mathrm{mm} \text { ) but numerous } \\
\text { vesicles (at least } 4 \text { per } 5 \times 5 \mathrm{~mm} \text { area) }\end{array}$ \\
\hline \multirow[t]{2}{*}{ IV } & Vesicular Basalt & $\begin{array}{l}\text { Grey to dark grey, lightweight, numerous large vesicles ( } 2 \text { to } 5 \\
\mathrm{~mm} \text { in diameter) }\end{array}$ \\
\hline & Undetermined & $\begin{array}{l}\text { Vesicular basalt that could not be categorized as either I, II or } \\
\text { IV }\end{array}$ \\
\hline
\end{tabular}

The most commonly used type of basalt was the vesicular basalt type I and the second most common type was the non-vesicular type II (Figure 3). The least dense basalt type IV represents only two percent of the total assemblage. This shows that toolmakers preferred denser basalt types with few vesicles when choosing raw material for tool production, which could be related to the greater compressive strength of non-vesicular basalt (Wright 1992). Dense basalt is also more easily shaped through flaking, something that was experienced through personal experiments on local basalts. However it has been suggested that vesicular basalt is more resilient to wear as it has a natural roughness that requires less frequent rejuvenation of the active faces (Wright 1992).

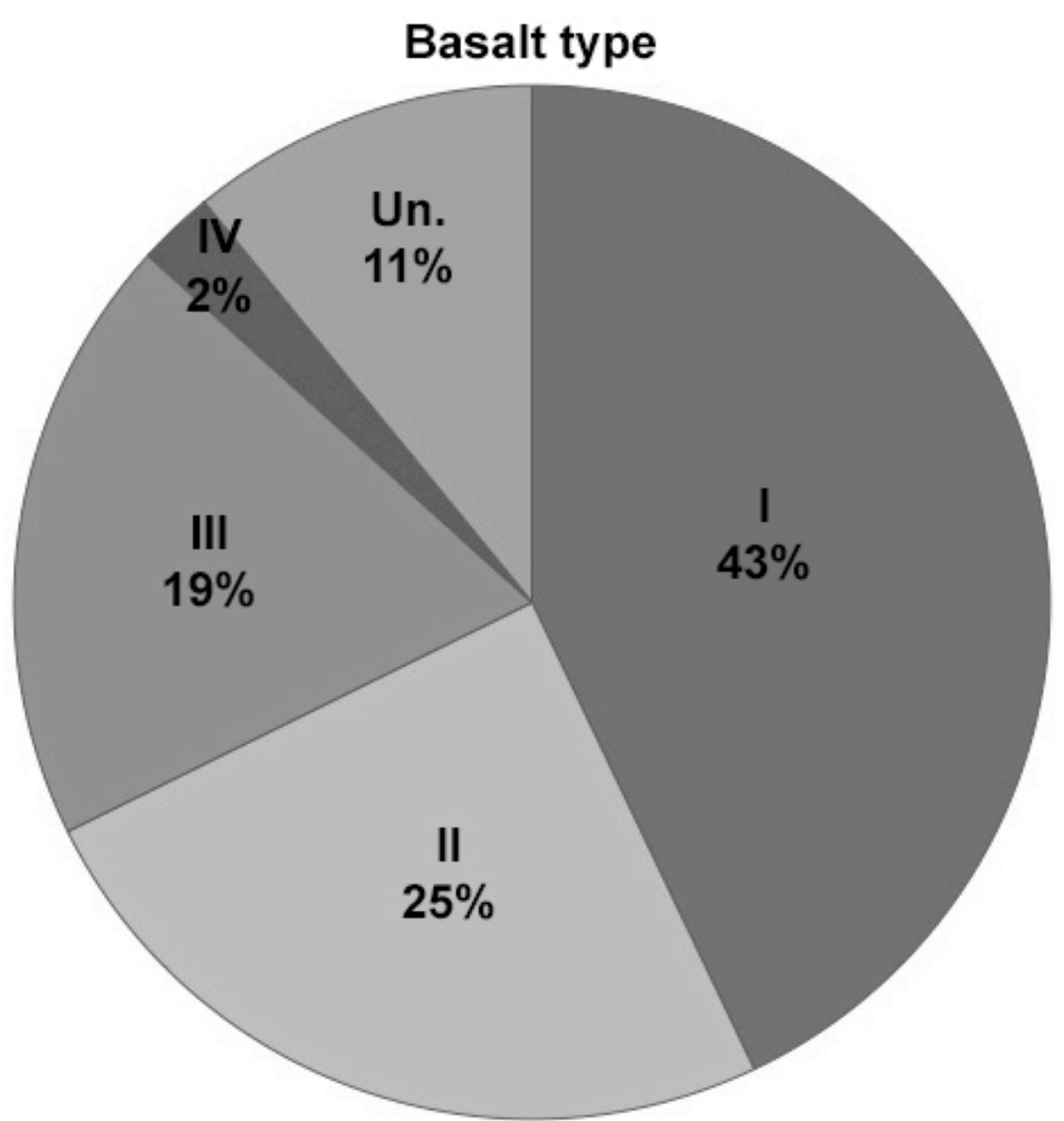

Figure 3: Raw material frequencies of basalt types in the Shubayqa 1 assemblage. The divisions were based on macroscopic observations (see Table 1). 
It could therefore be tentatively suggested that either durability of active faces was not the main concern when choosing raw material or other properties of less vesicular basalts, e.g., they are more easily flaked, simply made them more suitable as raw material for certain tools with particular functions. Confirming how raw material properties affect the production and function of tools will however require extensive experimental testing on the local basalts, primarily to verify whether the abovementioned assertions are actually true for vesicular and non-vesicular basalts. For this current study what remained possible was to correlate selected tool types with raw material types.

\subsubsection{Relationship between tools and raw material}

Here we examine the relationship between raw material choices and the four largest tool groups: handstones, lower grinding implements (henceforth LGI), pestles and mortar and vessels. The detailed descriptions of these tools are found below (see sections 4.2-4.5). Generally, as was observed above, vesicular basalt dominates these tool categories with the type I, being the most extensively used. It makes up approximately fifty percent in three of the four tool groups with the exception being mortars and vessels where it represents only forty percent and where type III is more common (see Figure 4).

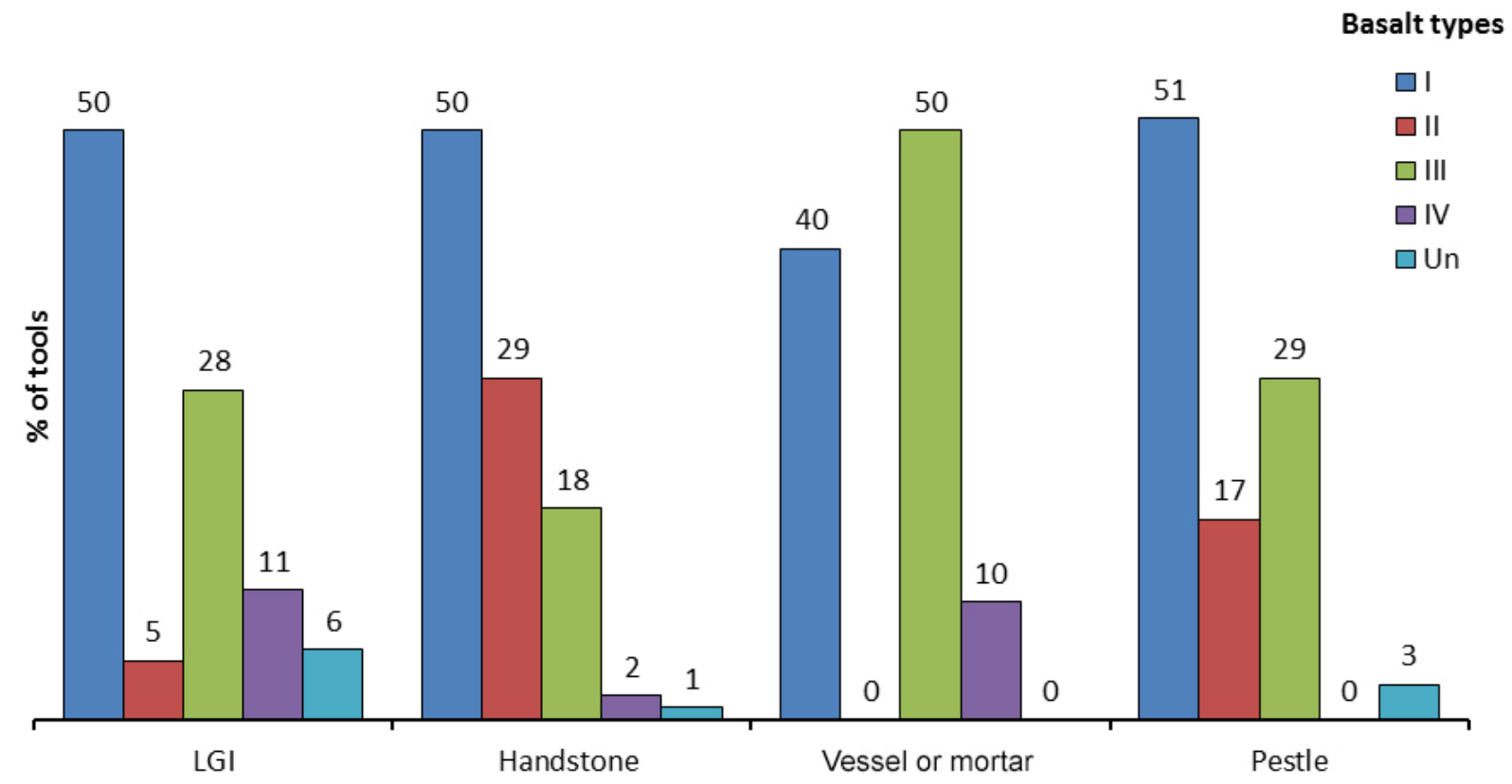

Figure 4: The relationship between tools and raw material types.

There seems to be a marked difference when it comes to raw material chosen for upper active tools (i.e. handstones and pestles) compared to lower stationary tools (i.e. LGI and mortar and vessels). Regarding upper active stones, twenty-nine percent of handstones and seventeen percent of pestles are made of non-vesicular basalt, suggesting that non-vesicular basalts have properties that are desirable in upper active stones, but not in lower stationary stones. As speculated above, this might have to do with the compressive strength (Wright 1992), which, at least in the case of pestles, can be an advantage as pounding is the action commonly associated with these tools (Adams 2002: 138). Also if we assume that nonvesicular basalt is more easily flaked this could perhaps suggest that handstones and pestles were more often flaked as part of their production. As noted above, vesicular basalt may be more durable than non-vesicular. This might be reflected in the basalts chosen for making lower stationary tools. Non-vesicular basalt is not utilized when producing mortar and vessels 
and hardly used for LGI (only five percent). If we assume, for the sake of argument, that these basalt types are more durable, it would suggest that durability was a desirable property in lower stationary tools. These tools usually last longer than the upper active tools (Adams 2002: 119 and references therein). As a consequence, more durable materials were chosen for the lower stationary tools, as it would be easier to make new handstones or pestles than new LGI or mortar and vessels. This suggests that flaking, or at least more controlled flaking, was not an equally important technique in the production of LGI and mortar and vessels, where pecking and abrading might have been more essential.

\subsection{Handstones}

Handstones make up the largest tool group in the Shubayqa 1 late Natufian assemblage (Figure 5). Handstones in this assemblage are defined as the active upper stone in a pair of grinding tools following Wright (1992). These tools have also been referred to as manos (Adams 2002: 99), processors (Rosenberg \& Gopher 2010), or rubbing stones (Moore 2000). They are used to pulverize an intermediate material between the active face of the handstone itself and the active face of the lower stationary stone in the pair through grinding using circular or reciprocal strokes (Wright 1992; Adams 2002: 41). The lower stationary stone in the pair is here referred to as lower grinding implements (see below).

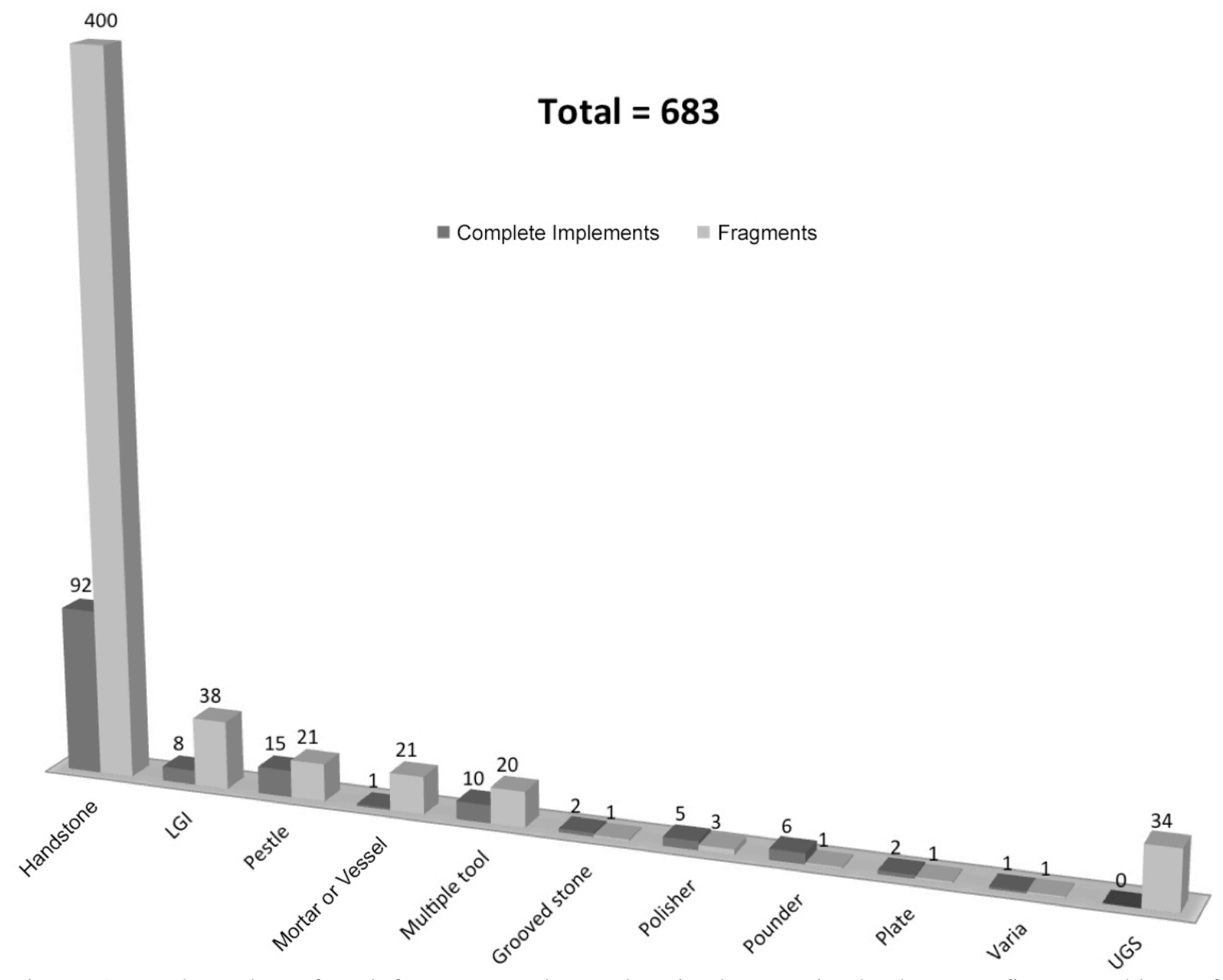

Figure 5: Total number of tool fragments and complete implements in the late Natufian assemblage of Shubayqa 1. 
The handstones were divided into types based on their planar shape (see Wright 1992). The transverse profile was also recorded, but profiles indicate use history and wearmanagement of the handstone and were therefore not considered separate types (Adams 2002: 113). Most common are elongated loaf-shaped types (61\%) (see Figure 6 no. 3, 5, 7 \& 10). Twenty-five percent of these taper at one or both ends, and are referred to as "loaf (tapered)" (see Figure 6 no. 1,). This shape is possibly the result of use and wear, but given the lack of experimental studies this cannot be confirmed at present. Profiles are generally triangular (31\%) with two opposite adjacent active faces (referred to as "wedge profile" in Adams (2002: 113 fig. 5.12) or plano-convex with a single active face (23\%). The remaining handstones are irregular (13\%), ovate (10\%) and discoidal (6\%) types (see Figure 6 no. 2, 4, $6,8,9,11+12)$. Ten percent of handstones were classified as unidentified handstone fragments (UHSF). These are fragments of handstones where exact type was not determinable.

\subsection{Lower Grinding Implements}

Lower grinding implements (LGI) are the second most common tool type (Figure 5). These are defined as the lower, stationary stone of a grinding tool pair (see Wright 1992). Most are querns, i.e. LGI with a round (or oval) active face displaying evidence for circular strokes with the upper active stone (handstone) by the grinder (Wright 1992). Five complete implements and 23 fragments were identified. There were two recurrent types that are subsequently referred to as opposed-faced double quern (ODQ) and stepped faced quern (SFQ).

The ODQ (Figure 7 no. 1) is classified as a block type quern (see Wright 1992). One face is oval in plan and a second face on the opposing surface is roughly circular in plan. A difference in depth between the two faces points to less usage of the circular face, suggesting that this is the secondary face. It would appear that the faces are consecutive; as the first face wore out a new face was used on the opposite surface.

Only fragments of the SFQ type have survived (Figure 7 no. 2). They are finely worked basin type querns (see Wright 1992), with flat to concave bases, smoothened exterior faces and a slight ridge rising above the quern face at the implement's edges. The stepped appearance of the SFQ-type faces is the result of a later face piercing the original more shallow use face. Whether this is re-using an expired quern or re-designing the use face is difficult to ascertain. The new face must have been narrower than the old since the second face's edge is some way from the ridge of the implement. The second face also appears to be deeper.

Two complete implements and 13 fragments are classified as slabs, i.e. LGI where wear and striations indicate reciprocal grinding in a linear lateral direction with the handstone by the grinder (Wright 1992). Thirteen LGI were installed into the stone pavement inside Structure 2. This includes a basalt flagstone with a cupmark and a mortar hole (Figure 7 no. 3). These installations suggest that the interior of Structure 2 was used as a work area.

\subsection{Pestles}

Pestles are the third largest tool group consisting of 36 pieces. These are the upper mobile stone in a pair of pounding tools (Wright 1992). Mortars are the lower stationary stones in the pair (see below). Similar to grinding tools the primary function of a pair of pounding tools is pulverizing intermediate material. This is achieved through the action of pounding which is defined as a forceful downward stroke (Adams 2002: 42). The most common pestle type is the cylindrical pestle. Most of these have sub-circular (52\%) or oval (43\%) profiles (Figure 8 no.1-4). Of the seven complete pestles five had two active ends and 
only two had one active end. Second most common pestle type is the conical pestle (Figure 8 no. 5). Most of these (67\%) have sub-circular profiles. Of the complete specimens, two are bipolar and three are unipolar. Three were classified as irregularly shaped pestles and appear to have been ad-hoc pestles.

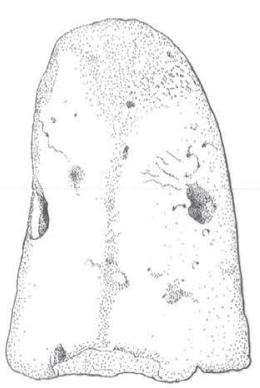

1.
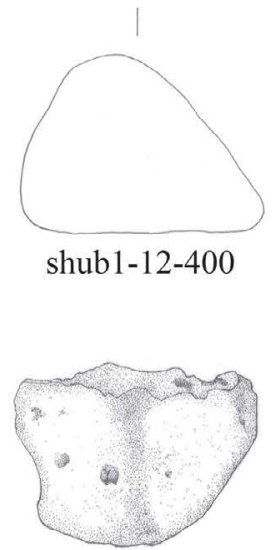

5.

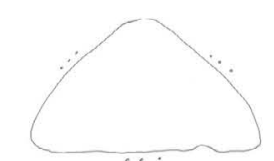

shub1-12-326

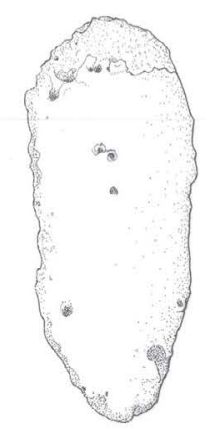

9.

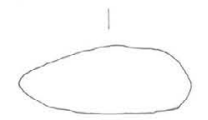

shub1-12-396

shub1-12-311

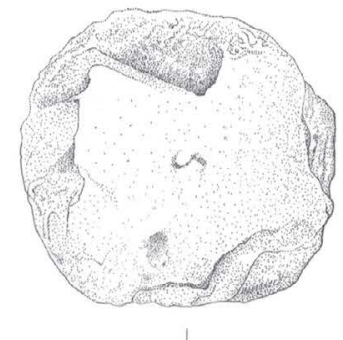

2.

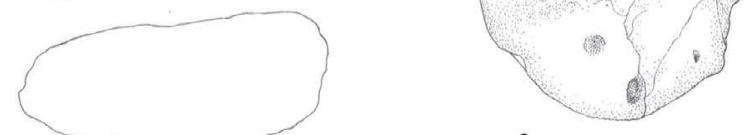

shub1-12-066

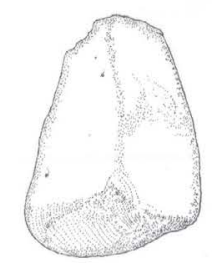

6.

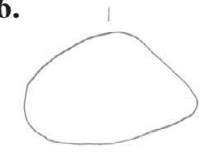

shub1-12-390

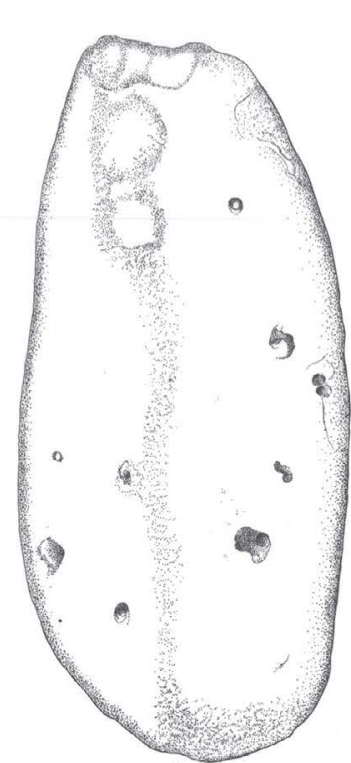

10.

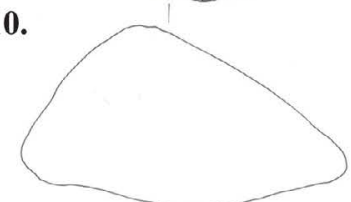

3.
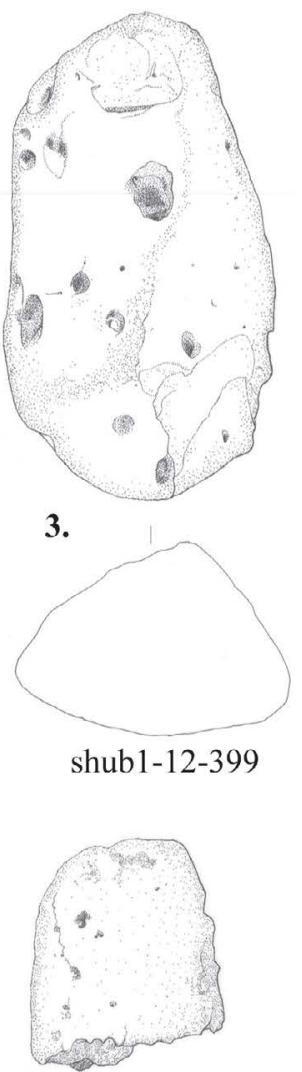

7.

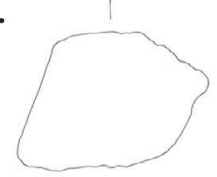

shub1-12-397

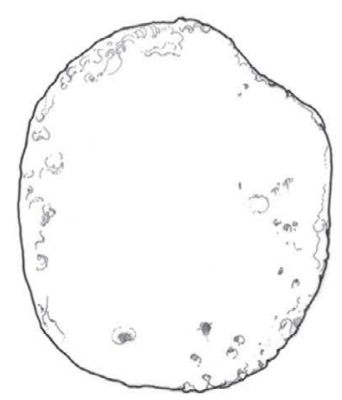

11.

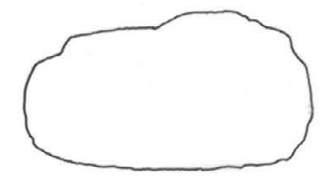

from Richter et al. 2012

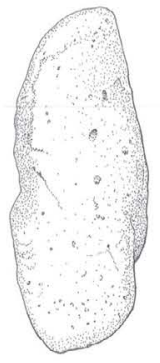

4.

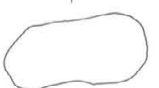

shub1-12-368

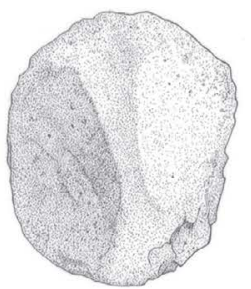

8.

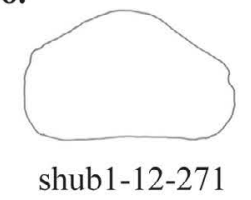

$\stackrel{\longmapsto}{30 \mathrm{~mm}}$

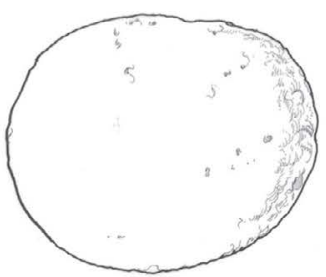

12.

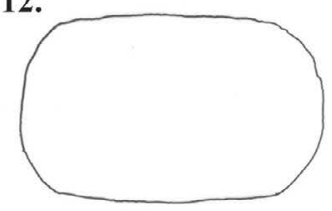

from Richter et al. 2012

Figure 6: Complete handstones and handstone fragments from the late Natufian phases of Shubayqa 1. 
1.

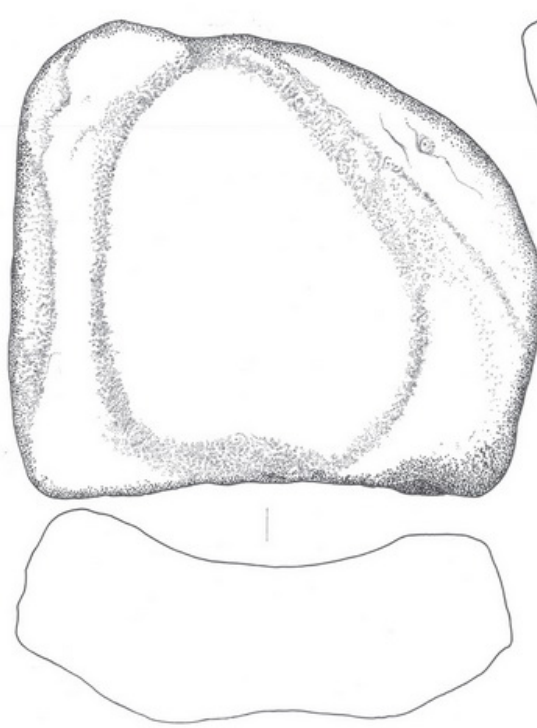

2.
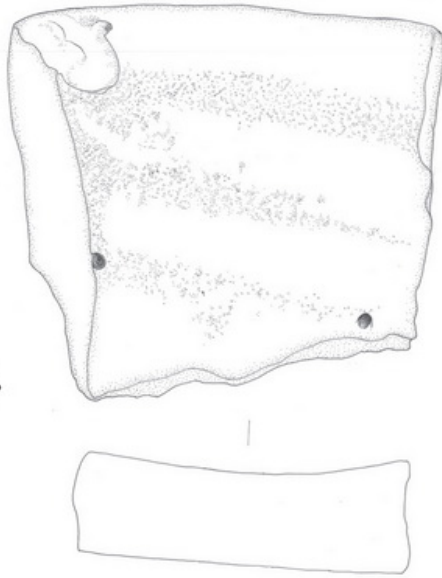

3.
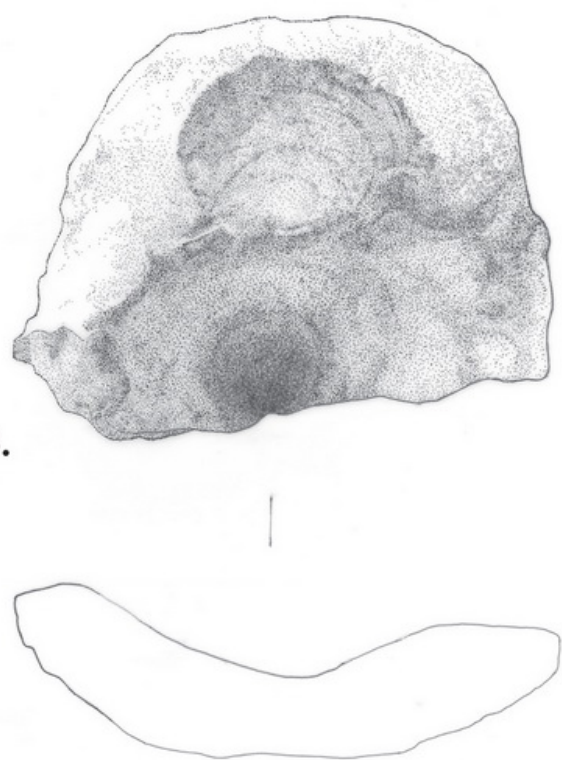

shub1-12-282

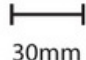

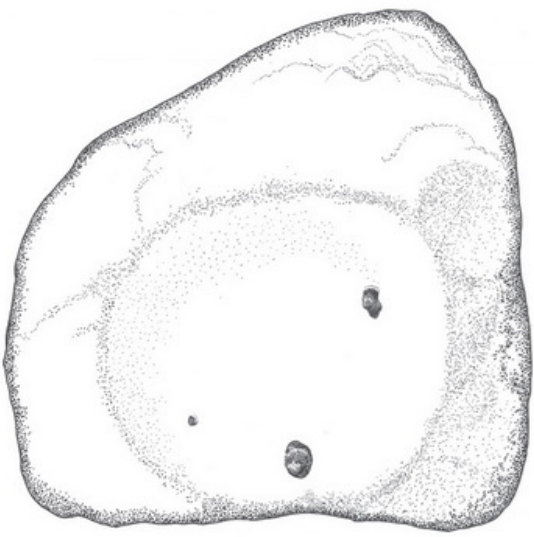

$30 \mathrm{~mm}$

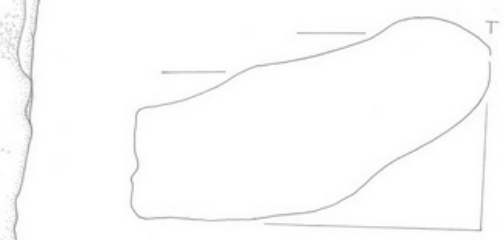

shub1-12-367

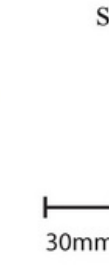

shub1-2013-407
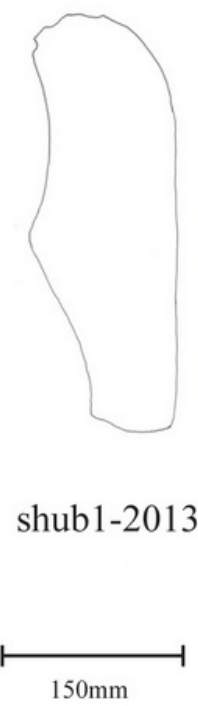

Figure 7: Lower Grinding Implements (LGI). No. 1: Complete quern of the type "opposed-faced double quern” (ODQ), No. 2: Fragment of the “stepped-faced quern” (SFQ) type, No. 3: Broken flagstone with cup-hole and mortar hole lifted from the floor surface of Structure 2, late Natufian phase of Shubayqa 1. 

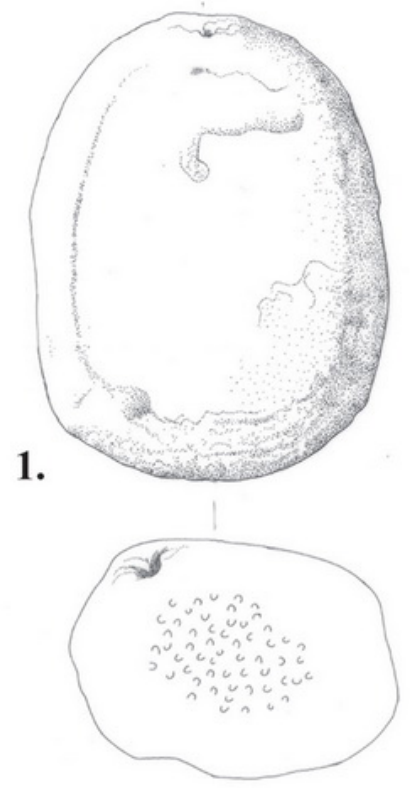

shub1-12-306
2.

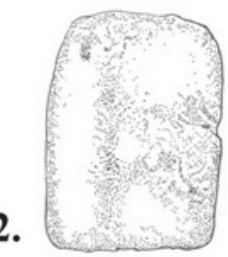

shub1-12-296
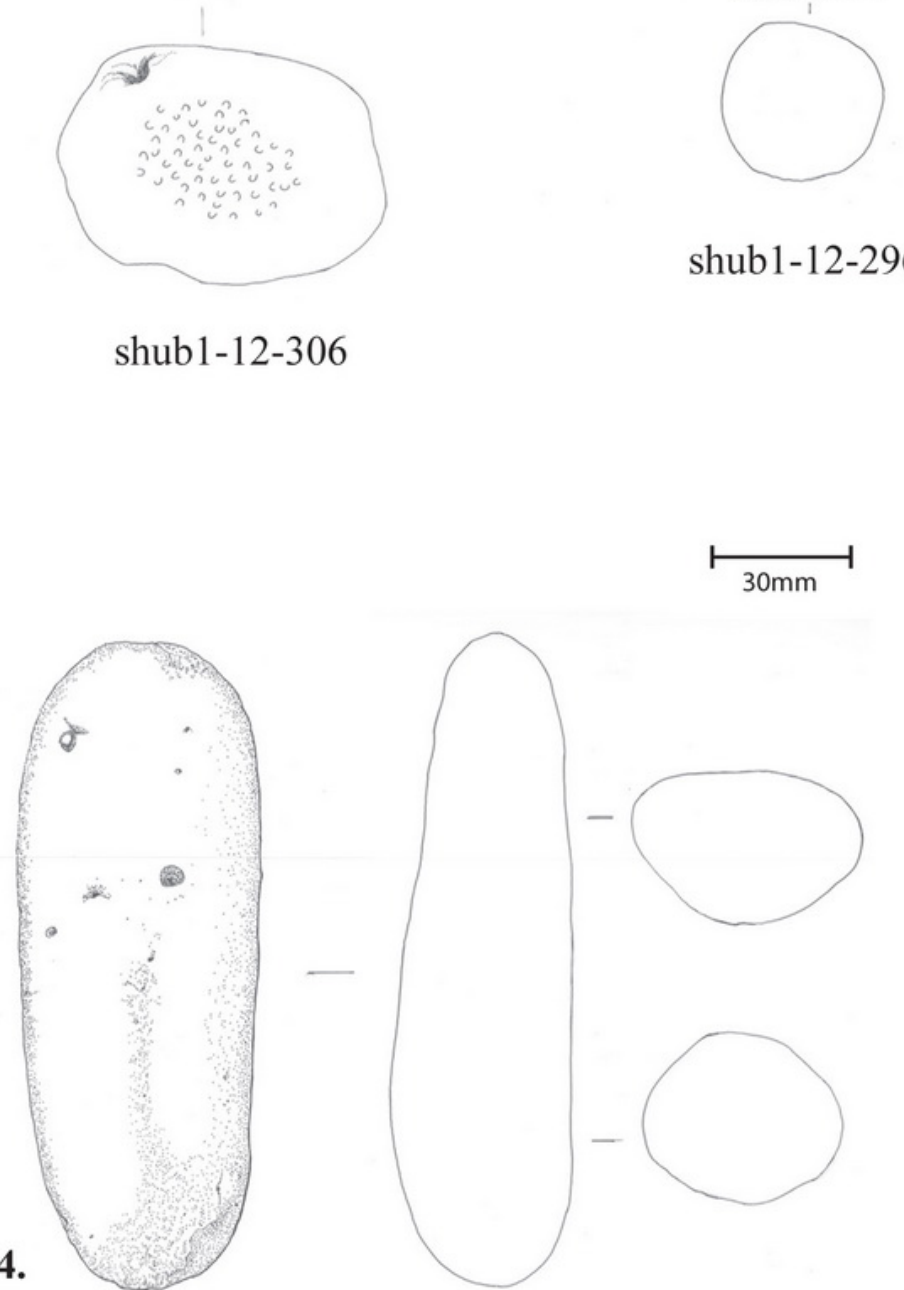

shub1-12-307

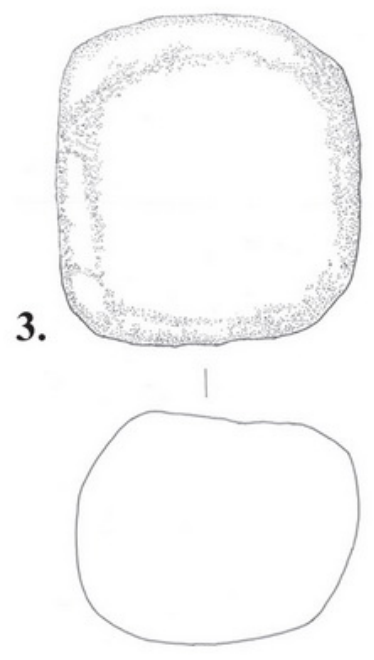

shub1-12-084

5.

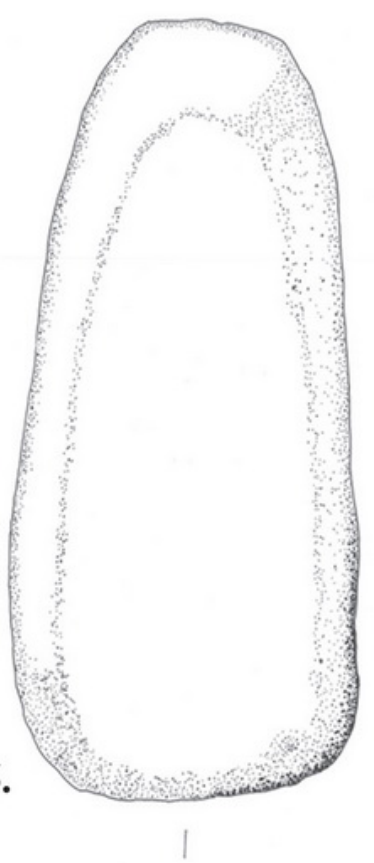

shub1-12-350

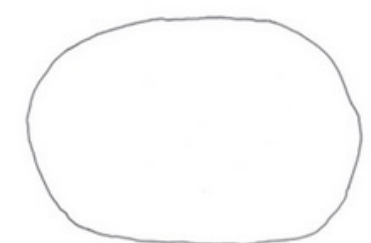

Figure 8: Complete pestles from the late Natufian phases of Shubayqa 1. 


\subsection{Mortars and Vessels}

Mortars are the lower stationary stones in pounding tool pairs (Wright 1992). The mortars and vessels of Shubayqa 1 comprise nine fragments and one complete boulder mortar, excluding the boulder mortars found on the surface. The complete in situ mortar was set into the floor of Structure 2 and has a mortar hole, ca. $26 \mathrm{~cm}$ in diameter and a depth of ca. $29 \mathrm{~cm}$ with a conical profile shape (Figure 9). It would appear that this was a pounding station positioned in the floor of the structure. The remaining fragments are of globular vessel-mortar types (Figure 10.1) and two goblet types (Figure 10.3). The fragments appear to be quite similar to fragments of mortars found at the early Natufian site Wadi Hammeh 27 near Pella in Jordan (see Edwards 2013: 218, fig. 8.10).

\subsection{Plates and palettes}

A plate or palette covered in pigment (Figure 11 no. 2) was also identified. It is $109 \mathrm{~mm}$ in diameter and $33 \mathrm{~mm}$ thick and has a discoid shape in plan and a shallow concave face. The plate may have been used as a sort of palette for mixing or containing pigment or that small amounts of ochre were ground on the face. In addition to this two plate fragments are present.

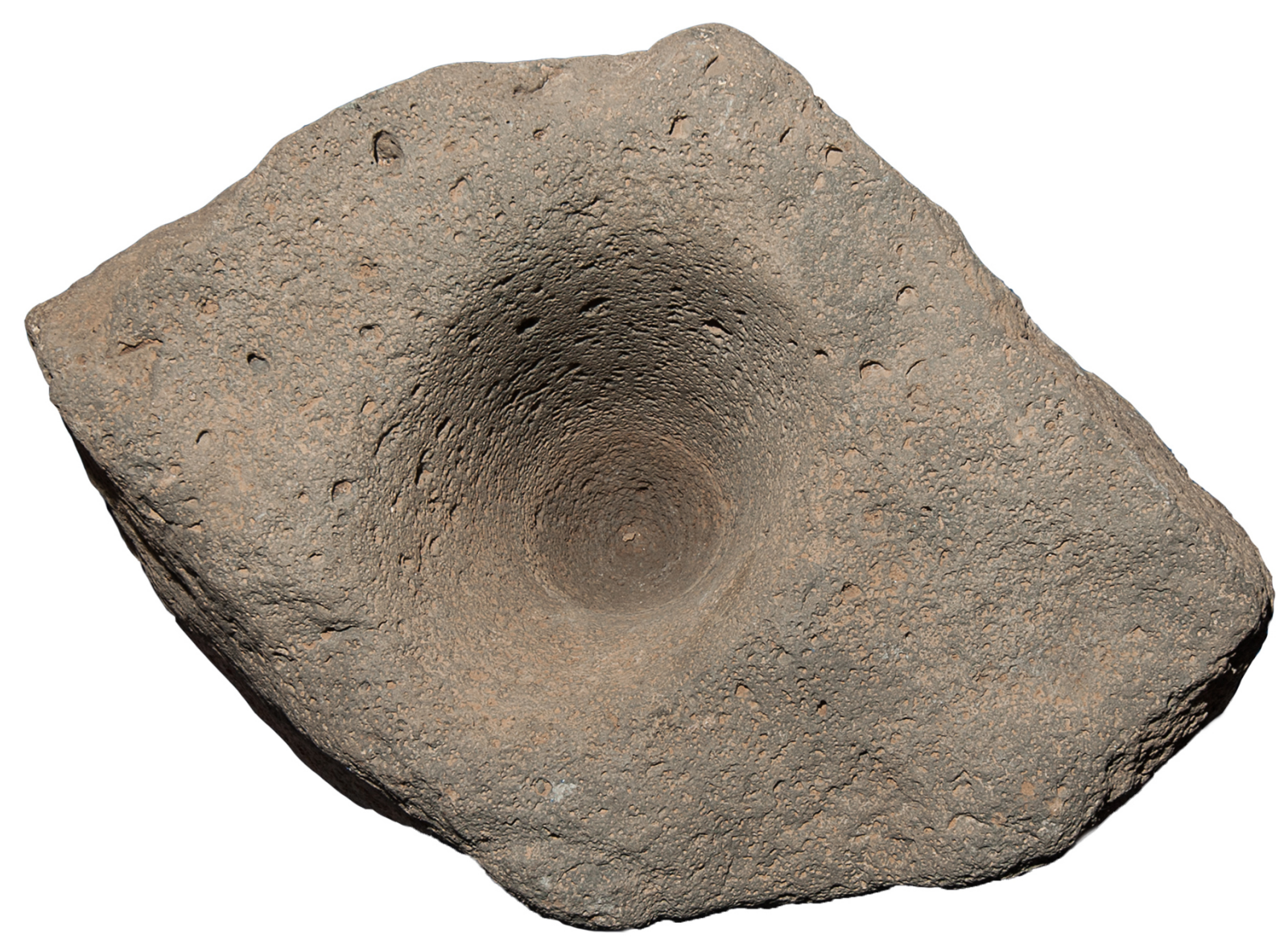

$50 \mathrm{~cm}$

Figure 9: Complete boulder mortar recovered from the floor surface of Structure 2, late Natufian phase of Shubayqa 1 (see also Figure 2). 


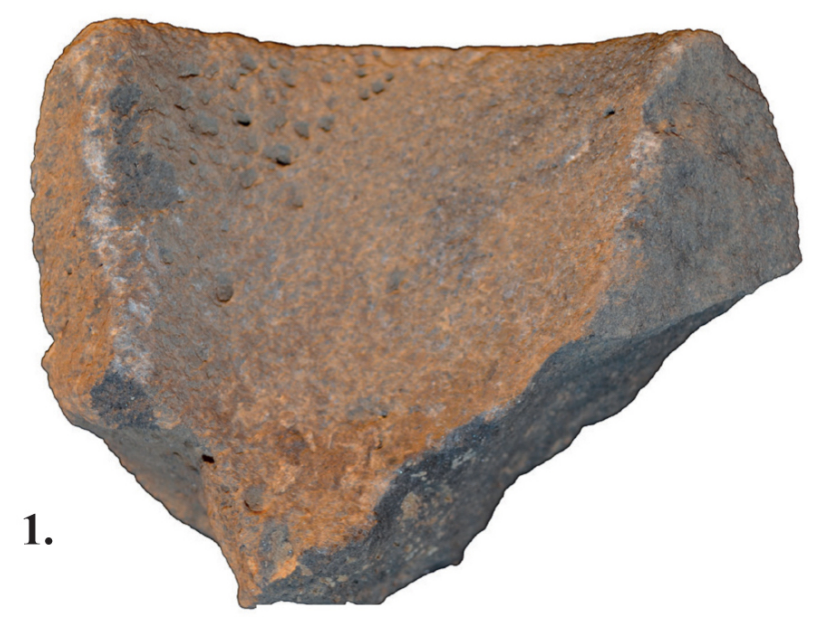

shub1-2013-239

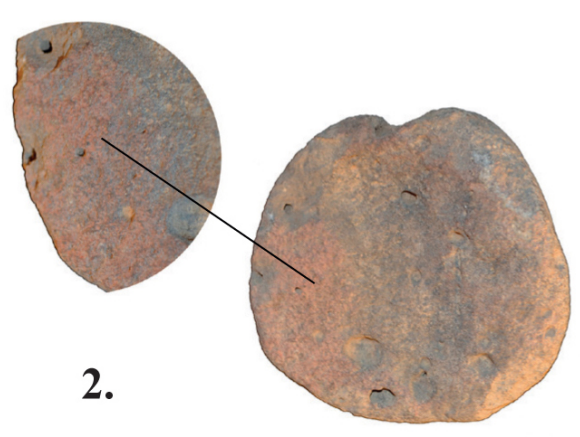

shub1-2013-518
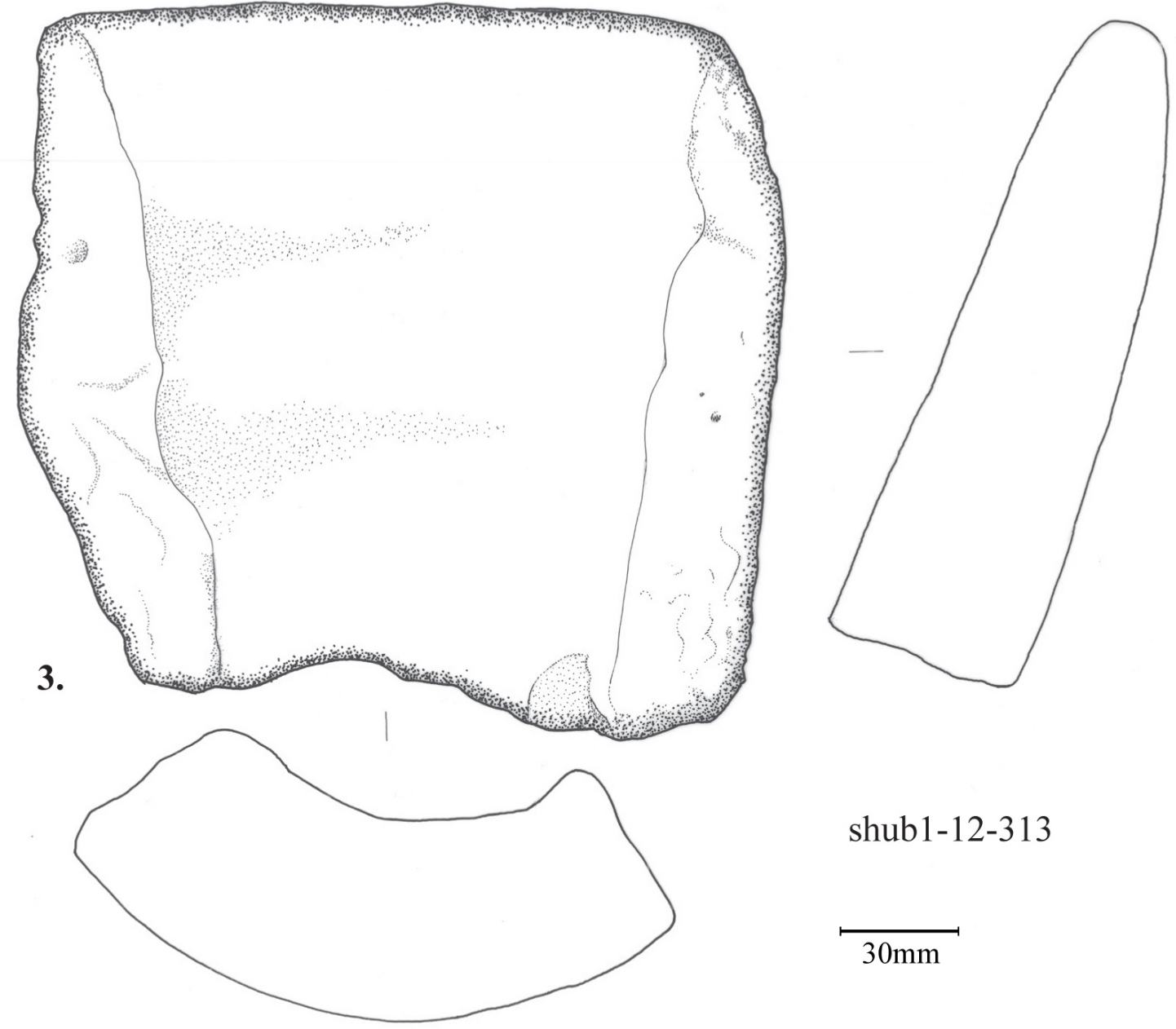

Figure 10: Mortars. No. 1: Fragment of globular type vessel-mortar, No 2: Complete plate or palette stained by ochre, No. 3: Fragment of goblet type vessel-mortar. 


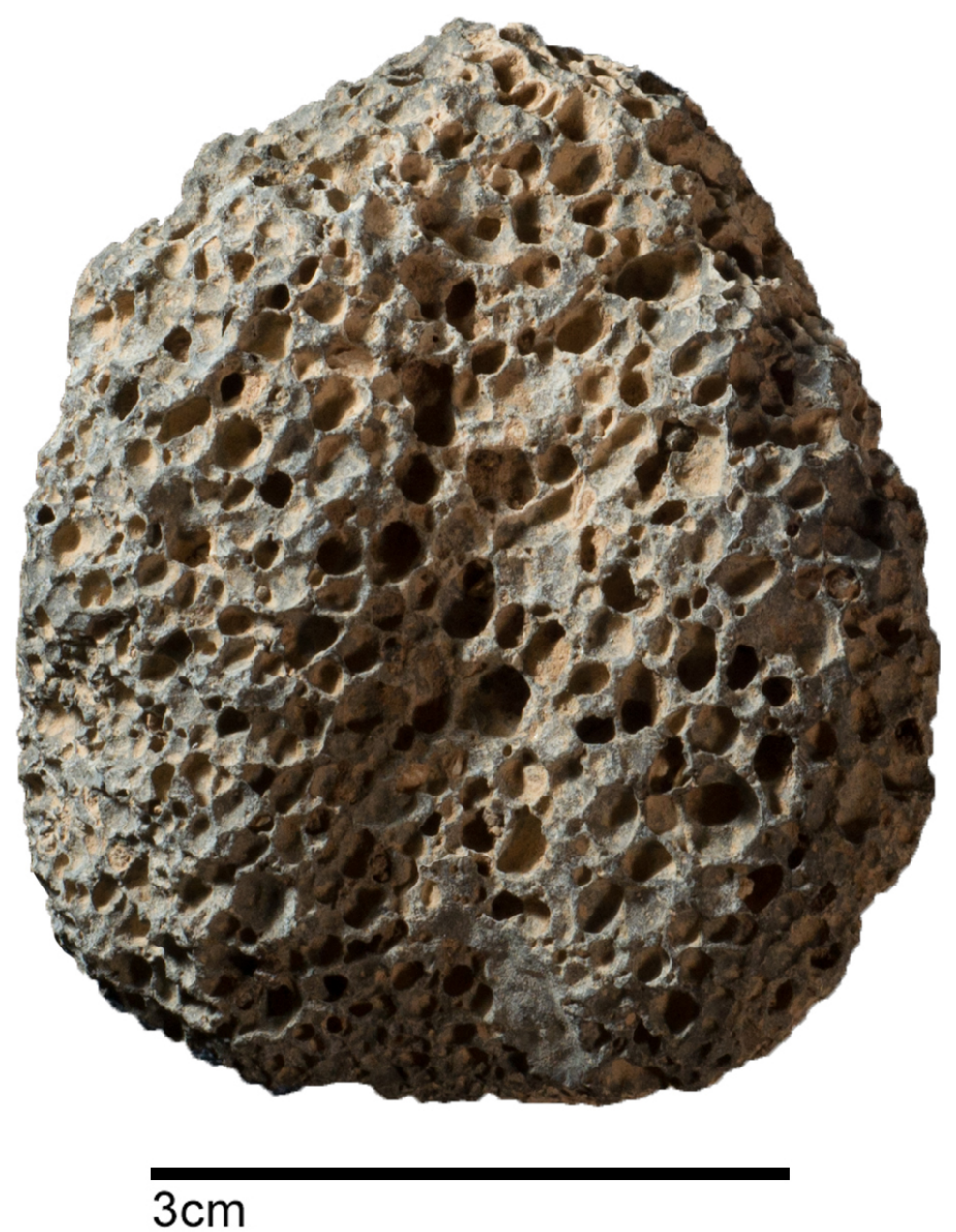

Figure 11: Grooved stone of scoria with a small bone fragment stuck in one of its vesicles.

\subsection{Miscellaneous}

Miscellaneous tools were defined as a group of less frequent tool types, consisting of polishers, pounders, grooved stones, varia and handstones. Eight artefacts and fragments were classified as polishers. Polishers can be distinguished from handstones by the sheen (polish) on their active face. In addition, instead of processing intermediate material between itself and a LGI, a polisher is used for smoothing the surface texture of another object (Adams 2002: 91). They were presumably used to smooth other stone objects, which leads to the creation of a quite pronounced sheen on the polisher (Adams 2002: 94). Most types present at Shubayqa are ovate shaped, with a lenticular profile. One polisher was made of flint and the rest of basalt.

Pounders consist of six complete implements and one fragment. One is made of flint and the remaining are of basalt. Four of these are spheroid pounders with a diameter ranging between $80 \mathrm{~mm}$ and $55 \mathrm{~mm}$. There seems to be a preference for using scoria instead of basalts when manufacturing grooved stones. Two of the three grooved stones are made of this rock type, one of which is complete with an ovate planar shape. The groove is v-shaped, and runs laterally through the centre of the entire length of the stone.

Varia includes artefacts that do not fall into any of the other categories. It consists of two pieces. One of them is a fragment of a stone ring, which was perhaps used as a polisher or handstone. One of its faces is slightly concave, while the opposing face is slightly convex. The second example is a very smooth pebble of non-basalt, unidentified rock type. 
The category of Unidentified Ground stone (UGS) consists of 34 fragments (five percent of the Shubayqa 1 late Natufian assemblage). This category is defined as fragments unidentifiable as anything other than worked stone. All have at least one recognizable used or worked face; most of them are very small fragments. Grouped within this category is debitage, which appears to be primarily basalt flakes. Future study of the debitage is planned and it will subsequently be separated from the UGS category.

\subsection{Multiple tools}

Multiple tools, defined here as tools that were used for two or more functions, e.g., grinding and pounding. In all 30 pieces of the assemblage were classified as multiple tools. Most of the multiple tools are pestle-handstones (70\%). They are loaf and ovate handstone types that were also used as pestles. Four of these were very large and were given the name heavy-duty pestle-handstones (HPH) (see Figure 12). The original size of these is unknown since all four specimens are fragments. Given the size of these fragments it appears that these tools were very large. All had battering marks at one end suggesting pounding and one face that displayed wear associated with grinding or abrading. Whether pestles of this size would have been useable is unclear but very large pestles are known from other Natufian assemblages (e.g., Edwards 2013: 224). Other examples of multiple tools include three handstone-grooved stones used for both grinding and abrading tasks and two complete handstone-cup-marked stones.

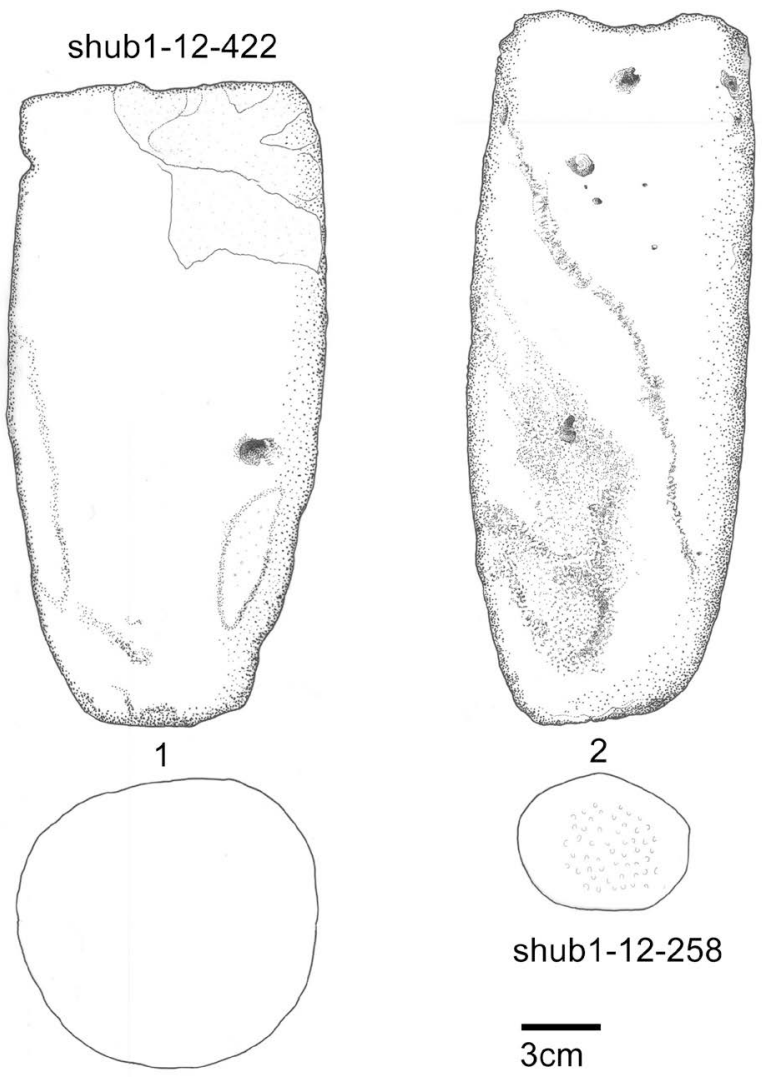

Figure 12: Fragments of very large pestle-handstone dubbed "heavy-duty pestle-handstone”. 


\section{Discussion}

It was initially thought that Natufian ground stone assemblages were dominated by pounding tools and that grinding tools played a less important role. Wright (1994) argued, however, that an increase in grinding tools at the expense of pounding tools could be observed during the transition from the early to the late Natufian. This has been confirmed by some other recent studies (e.g., Dubreuil 2004). The late Natufian ground stone assemblage from Shubayqa 1 is dominated by grinding tools such as handstones and LGI (79\%). Pounding tools, by contrast, make up just $8 \%$ of the total assemblage. The Shubayqa 1 late Natufian ground stone assemblage therefore appears to fit with the suggestion of Wright and Dubreuil that, generally speaking, an increase in grinding tools occurred during the late Natufian.

These frequencies are in accordance with data from other late Natufian occupations in the Levant, e.g., Tell Abu Hureyra and Eynan, which show an increase in grinding implements at the expense of pounding tools during the transition from the early to the late Natufian (Dubreuil 2004; Wright 1994, table 6-7). Having said that, it is also important to note that there is evidence for dual tool use in the Shubayqa 1 late Natufian assemblage. The pestle-handstones documented at Shubayqa 1 suggest that some handstones were also used as pestles and not exclusively as grinding implements. The idea that the distinction between pounding and grinding tools should not be viewed as definitive and that one tool type can have numerous functions is nothing new (e.g., Kraybill 1977 and references therein; Wright 1994; Adams 2002: 6-11; Rosenberg \& Gopher 2010). Several of the tools described here as "loaf shaped handstones" could be pestle-handstones used evenly for both pounding and grinding. Many of the handstone fragments did not have their ends preserved, and could thus theoretically also fall within the pestle-handstone group. Nevertheless, it shows that grinding was an important activity during the late Natufian occupation of Shubayqa 1. What was ground and pounded, however, is another question.

Wright (1994) challenged the notion that the late Natufian move towards grinding tools at the expense of pounding tools was indicative of a move towards a more cereal-based diet. This idea was in part rooted in the assumption that mortars and pestles were used in the early Natufian mainly for processing nuts like acorns in Mediterranean woodland areas of the Levant (see Wright 1994). Notwithstanding recent studies (see Terradas et al. 2013; Eitam et al. 2015) that have emphasized the role of rock-cut pounding tools in cereal processing, it has been argued that both pounding tools and grinding tools can be used for both cereal processing and processing of nuts (Kraybill 1977; Wright 1994 and references therein; Olszewski 2004). Recent use-wear analyses of Natufian ground stone tools (Dubreuil \& Grosman 2009, 2013) indicate that some tool functions cannot be assumed merely on the basis of form. This implies that the idea that grinding tools are necessarily related to the processing of cereals cannot be supported. An increase of grinding tools at the expense of pounding tools should not be viewed as definitive evidence of a move towards more cereal processing. Likewise, pounding tools are not necessarily related to cereal processing.

Shubayqa 1 provides a further twist to this idea. Archaeobotanical data from Shubayqa 1 shows that plant storage of organs (rhizome tubers) of the sedge family are a very common plant type in the assemblage (Figure 13) (see Richter et al. 2014). Although cereals are also present, these rhizome tubers likely constituted an essential food source for the late Natufian inhabitants of Shubayqa 1. The nutritional value of rhizome tubers of, for example Cyperus rotundus, are high in carbohydrate (25-30\%) and fibre $(+12 \%)$, but have a low amount of protein (2.5\%) and fat (1.6\%) (see Hillman et al. 1989 and references therein). Cyperus tubers have been shown to have an overall calorific return of $4.435 \mathrm{kcal} / \mathrm{hr}$, a yield superior to most cereals (Wright 1994: table 2 and references therein). 


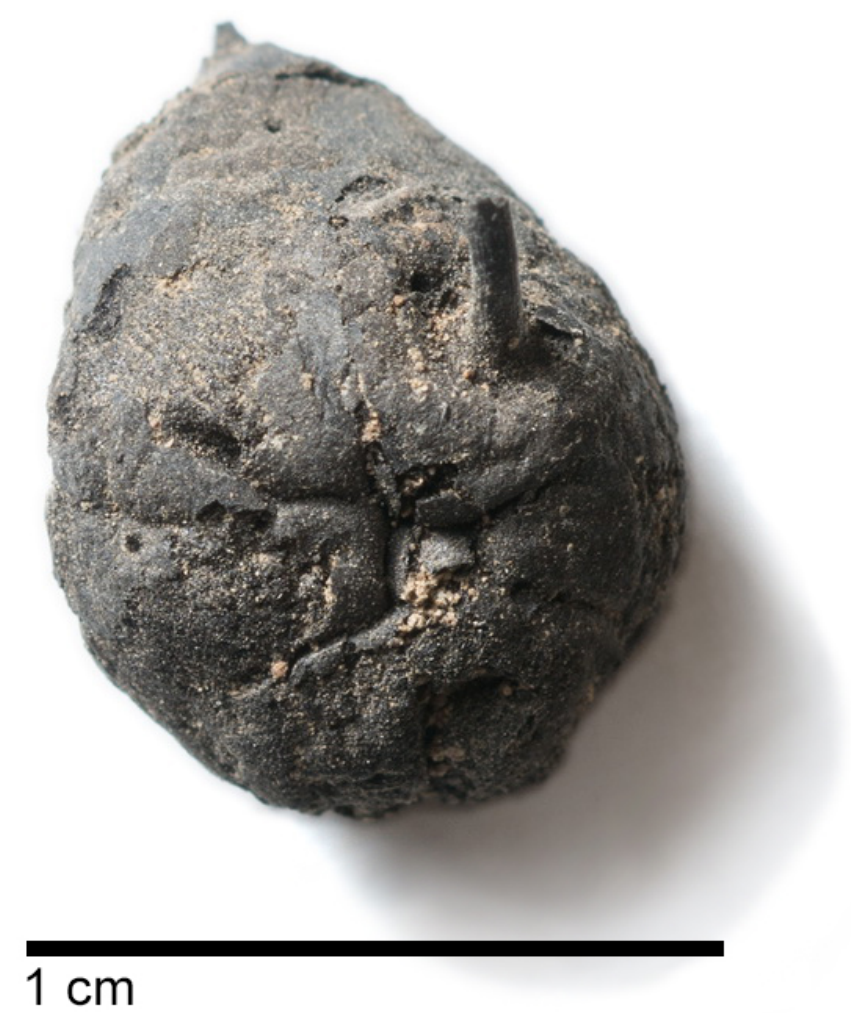

Figure 13: Charred Cyperaceae rhizome tuber (plant storage organs) from Shubayqa 1.

Recent studies have suggested that carbohydrates may have played a much more important dietary role in human evolution than previously recognized (Hardy et al. 2015). Ethnographic records suggest that both hunter-gatherer and agrarian societies across the globe ate Cyperaceae tubers (Hillman et al. 1989; Rivera et al. 2011: 395). Informed by such ethnographic evidence, Wollstonecroft et al. (2008) conducted experiments to analyse the way in which tubers of Bolboschoenus maritimus (L.) Palla of the Cyperaceae family, may have been processed for food in the past. The process involves pounding and grinding dried tubers into flour and then using that flour to cook flatbread or gruel. Grinding and pounding would help remove the coarsest of the fibres and destroy toxins like tannin (Hillman et al. 1989) and grinding of dried (or roasted) tubers would have increased the amount of edible product and reduced them to a more digestible flour (Wright 1994 and references therein; Hillman et al. 1989). Grinding can also potentially promote the release of nutrients through cell-rupture and cell-separation (Wollstonecroft et al. 2008).

At Shubayqa 1, high concentrations of Cyperaceae rhizome tubers were found in the ashy fill of stone-lined fireplaces, suggesting that heating or roasting of the tubers was a common activity during the Natufian. Given the need to break down roasted tubers by grinding and pounding, we hypothesize that many of the Shubayqa 1 ground stone implements were used to process this type of plant food. This evidence is matched by additional archaeological data from Wadi Kubbaniya in Egypt's Nile Valley (Close 1989). Similarly to Shubayqa 1 the ground stone assemblage at the late Paleolithic site E-78-3 is dominated by grinding tools (Roubet 1989), while Cyperaceae tubers (Cyperus Rotundus) were the most common plant remains. In all seven whole and 43 fragments of Cyperus Rotundus rhizome tubers were recovered from late Palaeolithic contexts (Hillman et al. 1989: table 7.1). Hillman suggested that these were brought to the site to be used as food. Bolboschoenus nutlets were also common at Tell Abu Hureyra (Wollstonecroft et al. 2011), a late Natufian site where a high number of grinding versus pounding tools was also observed (Wright 1994: table 7; Hillman 
2000; Moore 2000). Furthermore recent phytolith evidence from a late Natufian bedrock feature at Raqefet cave may also suggest tuber exploitation (Power et al. 2014).

Although additional, and more in-depth, studies are required, our initial evidence suggests that it is possible, even likely, that some of the late Natufian, and probably also early Natufian, grinding and pounding implements were used to pulverize Cyperaceae rhizome tubers to prepare flour and or gruel. This evidence stands in contrast to the idea that grinding or pounding tools were specifically related to either processing cereals or nuts. Further work on the Shubayqa 1 ground stone assemblage will aim to apply experimental studies, use-wear and trace analysis to determine what these tools were used for and whether tubers were processed in this manner.

While we hypothesize that many ground stone implements from Shubayqa 1 were used to process plant storage organs (rhizome tubers), a range of macroscopic observations also show that this was not the only activity these tools were used for. The processing of pigments could be observed easily by macroscopic inspection. At Shubayqa 1, five percent of handstones and sixteen percent of LGI in the late Natufian assemblage showed evidence of pigment grinding, primarily ochre (Figure 14).
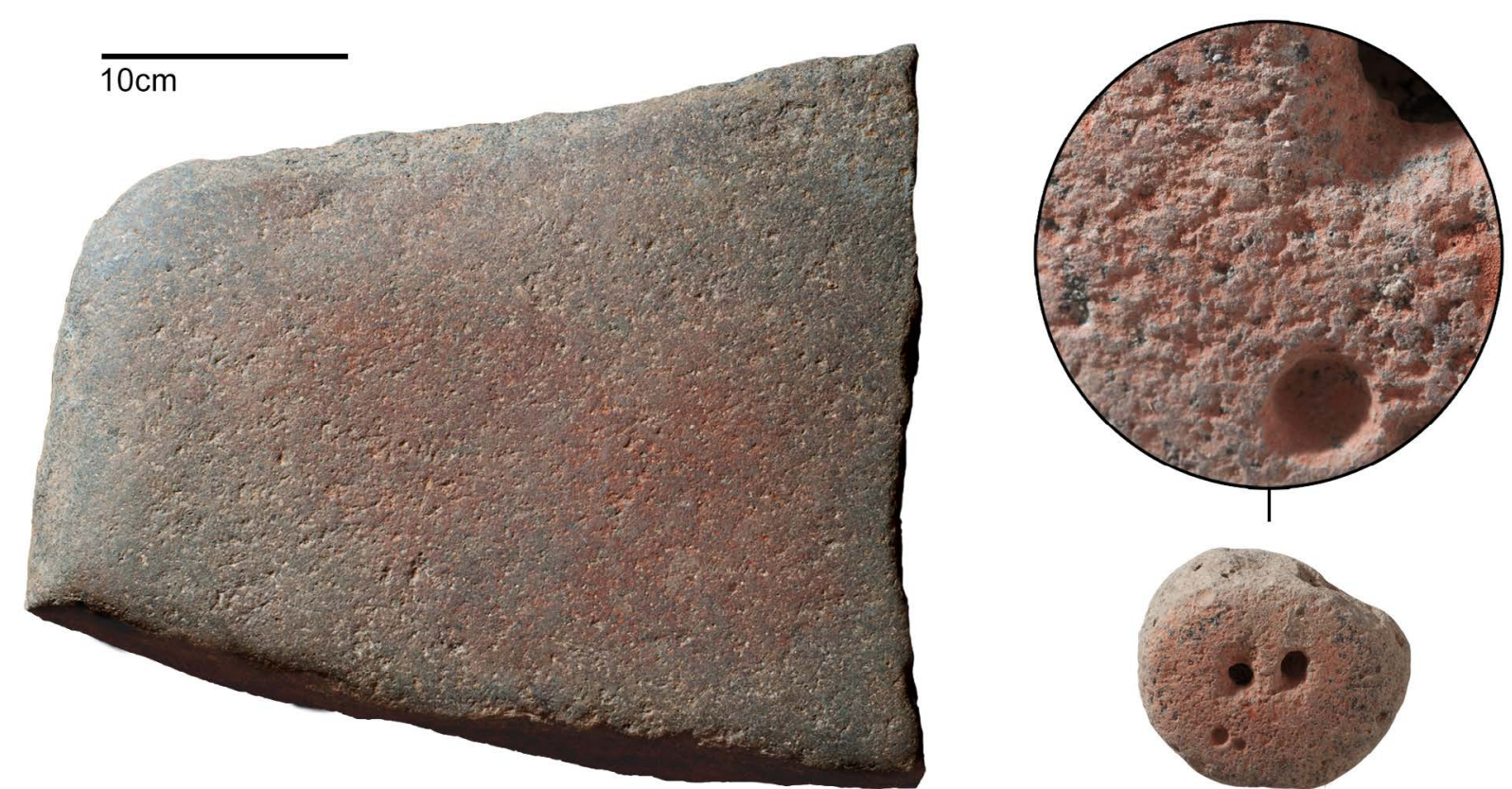

Figure 14: A grinding slab (left) and handstone (right) stained by ochre, presumably the result of pigment crushing.

Pigmented implements are not uncommon in the Natufian. At Wadi Hammeh 27, five percent of all pounding and grinding implements showed evidence of pigment processing (Edwards 2013: 232-233 \& table 8.2) and pigment traces on numerous of the Abu Hureyra LGI have also been noted (Moore 2000: 167-168). Dubreuil's (2004) landmark use-wear study of ground stone tools from the Natufian demonstrated that many late Epipalaeolithic ground stones were used to process a wide range of materials other than vegetal matter or meat. The processing of pigments could also be related to hide processing or decorating the human body (i.e. as bodily paint). Given the presence of several sub-floor human burials associated with Structure 2, pigment may have also played a role in burial ceremonies or other special events. In addition, a link between boulder mortars and burial customs in the Natufian has recently been explored by Rosenberg \& Nadel (2014). Nonetheless it is still the case that non-subsistence related uses of ground stone tools are often overlooked, but these may have 
played a significant role in shaping and determining the composition and character of Natufian ground stone assemblages.

\section{Conclusions}

The Shubayqa 1 assemblage offers the first comprehensive insight into the role of ground stone tools in the Natufian of eastern Jordan. It is the largest assemblage of ground stone excavated from secure late Epipalaeolithic contexts in the southeastern part of the Levant, and provides much needed evidence on how vegetal and other matter was processed in late Epipalaeolithic sites that are situated at the edge of the desert.

Our evidence shows the late Natufian assemblage of Shubayqa 1 is dominated by grinding tool pairs (i.e. handstones and LGI). In this Shubayqa 1 appears to follow a wider trend in the late Natufian towards greater variability (Wright 1994) and the greater importance of grinding implements (Wright 1993, 1994; Dubreuil 2004). At the same time, many tools from Shubayqa 1 also showed evidence of dual or multiple uses, as in the case of the pestlehandstones. This suggests that function does not necessarily follow tool form and that consequently the shift towards grinding may not have been as pronounced in the Shubayqa 1 assemblage at least.

In addition we argued that there has been an excessive focus on the importance of cereals in Natufian diets. Both grinding (e.g., Dubreuil 2004) and pounding (e.g., Wright 1994; Eitam et al. 2015) tools have been seen as indicative of cereal processing. Bearing in mind that the long-term success of cereals may have created a cultural bias (Byrd 1989; Olszewski 2004), evidence from Shubayqa 1 could suggest that grinding and perhaps pounding tools at this site were used to process another type of plant food: plant storage organs (i.e. rhizome tubers). On the basis of ethnographic and other archaeological evidence, we suggest that many ground stone tools from Shubayqa 1 could possibly be linked to the processing of these plant parts. This consequently emphasises that we should not assume that ground stone tools were primarily used for the processing of cereals or nuts. The availability and palatability of tubers and nutlets (Kraybill 1977; Hillman et al. 1989 and references therein; Wright 1994: table 2; Hillman 2000; Wollstonecroft et al. 2008, 2011) shows that these plants were likely just as important a food source as cereals. This could reflect certain resource specialization during the Natufian (Power et al. 2014). However, tubers are probably underrepresented in archaeological sites, due to their fragile anatomic structure and the types of recovery methods used to retrieve plant macro remains.

Finally, macroscopic evidence indicates that tools were also used to crush and grind pigments, and probably other materials. Consequently our preliminary evidence highlights the multi-functional and wide-ranging use of ground stone tools in this late Natufian assemblage, something that has previously been recognized (e.g., Wright 1994; Dubreuil 2004). This has clear implications for how we think about subsistence and site function in the Natufian, in particular with respect to sites outside the Mediterranean phytogeographical zone.

\section{Acknowledgements}

We wish to express our thanks to the conference organizers for inviting us to participate. We are grateful to the Department of Antiquities of Jordan for permission to work at Shubayqa 1. Research at Shubayqa has been supported by grants from the Danish Council for Independent Research, the Danish Institute in Damascus, Svend Fiedler og Hustrus Fond and the H.P. Hjerl Mindefondet for Dansk Palæstinaforskning. We would also like to thank A. Pantos for taking some of the photographs and G. Bjerre Thaarup for drawing the ground stone artefacts. 


\section{References}

Adams, J.L. 2002, Ground Stone Analysis: A Technological Approach. (1st ed.). University of Utah Press, Salt Lake City, 320 p.

Allison, R.J., Grove, J.R., Higgitt, D.L., Kirk, A.J., Rosser, N.J., \& Warburton, J. 2000, Geomorphology of the Eastern Badia Basalt Plateau, Jordan. The Geographical Journal, 166(4): 352-370. doi:10.1111/j.1475-4959.2000.tb00036.x

Bar-Yosef, O. 1996, The impact of late Pleistocene-early Holocene climatic changes on humans in southwest Asia. In: Humans at the End of the Ice Age: The Archaeology of the Pleistocene-Holocene Transition. (Straus, L.G., Eriksen, B.V., Erlandson, J.M., \& Yesner, D.R., Eds.), Plenum, New York: p. 61-76. doi:10.1007/978-1-4613-1145-4_4

Bar-Yosef, O. 1998, The Natufian culture in the Levant, threshold to the origins of agriculture. Evolutionary Anthropology, 6(5): 159-177. doi:10.1002/(SICI)1520.6505(1998)6:5<159::AID-EVAN4>3.0.CO;2-7

Bar-Yosef, O. 2002, The role of the Younger Dryas in the origin of agriculture in West Asia. In: The Origins of Pottery and Agriculture. (Yasuda, Y., Ed.), Roli/Lustre, New Delhi: p. 39-54.

Bar-Yosef, O., \& Belfer-Cohen, A. 2000, Early sedentism in the Near East: a bumpy ride to village life. In: Life in Neolithic Farming Communities. Social Organization, Identity, and Differentiation. (Kuijt, I., Ed.), Kluwer Academic, New York: p. 19-62. doi:10.1007/0-306-47166-3_2

Belfer-Cohen, A. 1991, The Natufian in the Levant. Annual Review of Anthropology, 20: 167186. doi:10.1146/annurev.an.20.100191.001123

Belfer-Cohen, A., \& Hovers, E. 2005, The ground stone assemblages of the Natufian and Neolithic societies in the Levant - a brief review. Journal of the Israel Prehistoric Society, 35: 299-308.

Betts, A.V.G. 1991, The late Epipalaeolithic in the Black Desert, eastern Jordan. In: The Natufian Culture in the Levant. (Bar-Yosef, O., \& Valla, F.R. Eds.), Ann Arbor: p. 217234.

Betts, A.V.G. 1998, The Harra and the Hamad. Excavations and Surveys in Eastern Jordan. Vol. 1. Sheffield Academic Press, Sheffield, 252 p.

Betts, A.V., \& Helms, S.W. 1991, Excavations at Jawa 1972-1986: Stratigraphy, Pottery and Other Finds. Edinburgh University Press, Edinburgh, 397 p.

Byrd, B.F. 1989, The Natufian: settlement variability and economic adaptations in the Levant at the end of the Pleistocene. Journal of World Prehistory, 3(2): 159-197. doi:10.1007/BF00975760

Close, A. 1989, Report on site E-78-3: a deeply stratified sequence of Early Kubbaniyan occupations. In: The Prehistory of Wadi Kubbaniya. Vol. 3, (Close, A., Ed.), Southern Methodist University Press, Dallas: p. 375-469.

Dubreuil, L. 2004, Long-term trends in Natufian subsistence: a use-wear analysis of groundstone tools. Journal of Archaeological Science, 31(11): 1613-1629. doi:10.1016/j.jas.2004.04.003

Dubreuil, L., \& Grosman L. 2009, Ochre and hide-working at a Natufian burial place. Antiquity, 83(322): 935-954. doi:10.1017/S0003598X00099269 
Dubreuil, L., \& Grosman L. 2013, The life history of macrolithic tools at Hilazon Tachtit Cave. In: Natufian Foragers in the Levant - Terminal Pleistocene Social Changes in Western Asia. (Bar-Yosef, O., \& Valla, F.R., Eds.), International Monographs in Prehistory. Ann Arbor, Michigan: p. 527-543.

Edwards, P.C. 2013, Wadi Hammeh 27, an early Natufian settlement at Pella in Jordan. Culture and History of the Near East Vol. 59. Brill, Leiden/Boston, 437 p. doi:10.1163/9789004236103

Eitam, D. 2009, Late Epipalaeolithic rock-cut installations and groundstone tools in the Southern Levant. Paléorient, 35(1): 77-104. doi:10.3406/paleo.2009.5279

Eitam, D., Kislev, M., Kaarty, A., \& Bar-Yosef, O. 2015, Experimental barley flour production in 12,500-Year-old rock-cut mortars in Southwestern Asia. PLoSONE, 10(7): e0133306. doi:10.1371/journal.pone.0133306

Garrard, A.N., Byrd, B.F., Harvey, P., \& Hivernel, F. 1985, Prehistoric Environment and Settlement in the Azraq Basin. A Report on the 1982 Survey Season, Levant, 17(1): 128. doi:10.1179/007589185790212105

Garrard, A.N. 1991, Natufian settlement in the Azraq Basin, eastern Jordan. In: The Natufian Culture in the Levant. (Bar-Yosef, O., \& Valla, F.R., Eds.), International Monographs in Prehistory. Ann Arbor, p. 235-244.

Garrard, A.N. 1998, Environment and cultural adaptations in the Azraq Basin: 24,000 - 7,000 B.P. In: The Prehistory of Jordan. (Henry, D.O., Ed.), British Archaeological Reports International Series Vol. 705. Archaeopress, Oxford: p. 139-148.

Garrard, A.N., Baird, D., \& Byrd, B.F. 1994, The chronological basis and significance of the late Palaeolithic and Neolithic sequence in the Azraq Basin, Jordan. In: Late Quarternary Chronology and Paleoclimates of the Eastern Mediterranean. (Bar-Yosef, O., \& Kra, R.S. Eds.), Radiocarbon, Ann Arbor: p. 177-199.

Garrard, A.N., Betts, A., Byrd, B.F., Colledge, S., \& Hunt, C. 1988, Summary of the palaeoenvironmental and prehistoric investigations in the Azraq Basin. In: The Prehistory of Jordan. The State of Research in 1986. (Garrard, A.N., \& Gebel, H.G., Eds.), British Archaeological Reports International Series Vol. 396. Archaeopress, Oxford: p. 311-337.

Garrard, A.N., \& Byrd, B.F. 1992, New dimensions to the Epipalaeolithic of the Wadi el-Jilat in central Jordan. Paléorient, 18(1): 47-62. doi:10.3406/paleo.1992.4562

Garrard, A.N., \& Byrd, B.F. 2013, Beyond the Fertile Crescent: Late Palaeolithic and Neolithic communities of the Jordanian steppe. The Azraq Basin Project Volume 1: Project background and the Late Palaeolithic (geological context and technology). Levant Supplementary Series Vol. 13. Oxbow, Oxford, 448 p.

Garrard, A.N., Price, S., \& Copeland, L. 1977, A survey of prehistoric sites in the Azraq Basin of eastern Jordan. Paléorient, 3(1): 109-126. doi:10.3406/paleo.1975.4192

Hardy, K., Brand-Miller, J., Brown, K. D., Thomas, M. G., \& Copeland, L. 2015, The Importance of Dietary Carbohydrate in Human Evolution. The Quarterly Review of Biology, 90(3), 251-268. doi:10.1086/682587

Henry, D.O. 2013, The Natufian and the Younger Dryas. In: Natufian Foragers in the Levant. Terminal Pleistocene Social Changes in Western Asia. (Bar-Yosef, O., \& Valla, F.R., Eds.), International Monographs in Prehistory. Ann Arbor, Michigan: p. 584-610. 
Hillman, G.C. 2000, The plant food economy of Abu Hureyra 1 and 2. In: Village on the Euphrates From Foraging to Farming at Abu Hureyra. (Moore, A.M.T., Hillman, G.C., \& Legge, A.J., Eds.), Oxford University Press, Oxford: p. 327-398.

Hillman , G.C., Madeyska, E., \& Hather, J. 1989, Wild plant foods and diet at Late Paleolithic Wadi Kubbaniya: evidence from the charred remains. In: The Prehistory of Wadi Kubbaniya. Vol. 2, (Close, A., Ed.), Southern Methodist University Press, Dallas: p. $162-242$.

Kraybill, N. 1977, Pre-agricultural tools for the preparation of foods in the Old World. In: Origins of Agriculture. (Reed, C., Ed.), Mouton, The Hague: p. 485-522.

Maher, L.A., Richter, T., \& Stock, J.T. 2012, The Pre-Natufian Epipaleolithic: long-term behavioral trends in the Levant. Evolutionary Anthropology, 21(2): 69-81. doi:10.1002/evan.21307

Moore, A.M.T. 2000, Stone and other artefacts. In: Village on the Euphrates From Foraging to Farming at Abu Hureyra. (Moore, A.M.T., Hillman, G.C., \& Legge, A.J., Eds.), Oxford University Press, Oxford: p. 165-186.

Olszewski, D. 2004, Plant food subsistence issues and scientific inquiry in the Early Natufian. In: The Last Hunter-Gatherer Societies in the Near East. (Delage, C., Ed.), British Archaeological Reports International Series Vol. 1320. John and Erica Hedges Ltd, Oxford: p. 189-209.

Perrot, J. 1966, Le gisement Natoufien de Mallaha (Eynan), Israël. L’Anthropologie, 70(5-6): 437-484.

Peterson, J. 1999, Early Epipaleolithic settlement patterns : Insights from the study of groundstone tools from the southern Levant. Levant, 31(1): 1-17. doi:10.1179/007589199790217204

Power, R. C., Rosen A. M. \& Nadel, D. 2014, The economic and ritual utilization of plants at the Raqefet Cave Natufian site: The evidence from phytoliths. Journal of Anthropological Archaeology, 33: 49-65. doi:10.1016/j.jaa.2013.11.002

Richter, T., Arranz Otaegui, A., House, M., Rafaiah, A., \& Yeomans, L. 2014, Preliminary report on the second season of excavation at Shubayqa 1. Neo-Lithics, 14: 3-10.

Richter, T., Bode, L., House, M., Iversen, R., Arranz, A., Saehle, I., Thaarup, G., Tvede, M.L., \& Yeomans, L. 2012, Excavations at the Late Epipalaeolithic site of Shubayqa 1: preliminary report on the first season. Neo-Lithics, 12: 3-14.

Richter, T., \& Maher, L.A. 2013, The Late Epipalaeolithic in the Azraq Basin: a reappraisal. In: Natufian Foragers in the Levant. Terminal Pleistocene Social Changes in Western Asia. (Bar-Yosef, O., \& Valla, F.R. Eds.), International Monographs in Prehistory. Ann Arbor, Michigan: p. 429-448.

Rivera, D., Matilla, G., Obon, C. \& Alcaraz, F. 2011, Plants and Humans in the Near East and the Caucasus. Ancient Traditional Uses of Plants as Food, and Medicine. An Ethnobotanical Diachronic Review. Vol. 1. Servicio de publicaciones Universidad de Murcia, Murcia, 341 p.

Rollefson, G.O., Quintero, L., \& Wilke, P. 1999, Bawwab al-Ghazal: preliminary report on the testing season 1998. Neo-Lithics, 1: 2-4. 
Rosen, S.A. 1991, Paradigms and politics in the Terminal Pleistocene archaeology of the Levant. In: Perspectives on the Past: Theoretical Biases in Mediterranean HunterGatherer Research. (Clark, G.A., Ed.), University of Pennsylvania Press, Philadelphia: p. 307-321.

Rosenberg, D., \& Gopher, A. 2010, Food processing tools and other ground stone implements from Gilgal I and Gilgal III. In: Gilgal Early Neolithic Occupations in the Lower Jordan Valley: The Excavations of Tamar Noy. (Bar-Yosef, O., Goring-Morris, A.N., \& Gopher, A., Eds.), Oxbow Books, Oxford and Oakville: p. 139-175.

Rosenberg, D. \& Nadel, D. 2014, The sounds of pounding: boulder mortars and their significance to Natufian burial customs. Current Anthropology, 55(6): 784-812. doi:10.1086/679287

Roubet, C. 1989, The grinding stones of site E-78-3, Wadi Kubbaniya. In: The Prehistory of Wadi Kubbaniya. Vol. 3, (Roubet, C., Ed.), Southern Methodist University Press, Dallas: p. 473-489.

Terradas, X., Ibáñez, J.J., Braemer, F., Hardy, K., Iriarte, E., Madella, M., Ortega, D., Radini, A., \& Teira, J.C. 2013, Natufian bedrock mortars at Qarassa 3: preliminary results from an interdisciplinary methodology. In: Stone Tools in Transition: From HunterGatherers to Farming Societies in the Near East. (Borrell, F., Ibáñez, J.J., \& Molist, M., Eds.), Universitat Autonoma de Barcelona, Barcelona: p. 441-456.

Valla, F.R., \& Christensen, M. 2012, Le material en pierre. In: Les Fouilles de la Terrasse D'Hayonim (Israel) 1980-1981 et 1985-1989. (Valla, F.R., Ed.), De Boccard, Paris: p. 299-319.

Wollstonecroft, M.M., Ellis, P.R., Hillman, G.C., \& Fuller, D.Q. 2008, Advances in plant food processing in the Near Eastern Epipalaeolithic and implications for improved edibility and nutrient bioaccessibility: an experimental assessment of Bolboschoenus maritimus (L.) Palla (sea club-rush). Vegetation History and Archaeobotany, 17(1): 19-27. doi:10.1007/s00334-008-0162-x

Wollstonecroft, M.M., Hroudová, Z., Hillman, G.C., \& Fuller, D.Q. 2011, Bolboschoenus glaucus (Lam.) SG Smith, a new species in the flora of the ancient Near East. Vegetation History and Archaeobotany, 20(5): 459-470. doi:10.1007/s00334-011-0305-3

Wright, K. 1991, The origins and development of ground stone assemblages in Late Pleistocene Southwest Asia. Paléorient, 17(1): 19-45. doi:10.3406/paleo.1991.4537

Wright, K. 1992, A classification system for ground stone tools from the prehistoric Levant. Paléorient, 18(2): 53-81. doi:10.3406/paleo.1992.4573

Wright, K. 1994, Ground-stone tools and hunter-gatherer subsistence in Southwest Asia: implications for the transition to farming. American Antiquity, 59(2): 238-263. doi:10.2307/281929

Zohary, M. 1973, Geobotanical foundations of the Middle East. Vol. 1. (Geobotanica selecta Band III S.h.c. R. Tüxen). Gustav Fischer Verlag, Stuttgart, 340 p. 